\title{
Öğrenci ve Mezunlarının Perspektifinden İmam Hatip Liselerinin Değerlendirilmesi*
}

\section{Evaluation of Imam Hatip High Schools from the Students and the Graduates' Perspective**}

\author{
Ömer Alper KARASUBAŞI, Öğretmen. \\ T.C. Milli Eğitim Bakanlığı, Türkiye. \\ omaralper@gmail.com \\ http://orcid.org/0000-0001-6399-2180 \\ Uğur AKIN, Sorumlu Yazar, Doç. Dr. \\ Tokat Gaziosmanpaşa Üniversitesi, Eğitim Fakültesi, Türkiye. \\ akinuur@gmail.com \\ http://orcid.org/0000-0002-4911-3781 \\ Nail YILDIRIM, Prof. Dr. \\ Kahramanmaraş Sütçü İmam Üniversitesi, Eğitim Fakültesi, Türkiye. \\ nailyildirim@ksu.edu.tr \\ http://orcid.org/0000-0002-4681-9498
}

ISSN: $1303-880 \mathrm{X}$

e-ISSN: 2667-7504

http://ded.dem.org.tr

Makale Türü / Article Type:

Araştırma Makalesi / Research Article

Geliş Tarihi / Received Date: 05.08.2019

Kabul Tarihi / Accepted Date: 19.12.2019

Yayın Tarihi / Published Date: 25.06.2020

Tr/En: $\operatorname{Tr}$

İntihal / Plagiarism: Bu makale, en az iki hakem tarafindan incelendi ve intihal içermediği teyit edildi. / This article has been reviewed by at least two referees and scanned via a plagiarism software.
Atıf/Citation: Karasubaşı, Ö. A., Akın, U., Yıldırım, N. (2020). Öğrenci ve mezunlarının perspektifinden imam hatip liselerinin değerlendirilmesi. Değerler Eğitimi Dergisi, 18(39), s.65-105. https://doi.org/10.34234/ded.602051

* Bu çalışma Öğretmen Ömer Alper Karasubaşı'nın, Prof. Dr. Nail Yıldırım danışmanlığında başlayan ve Doç. Dr. Uğur Akın danışmanlığında tamamlanan yüksek lisans tezinden üretilmiştir.

** This manuscript has been produced from the master thesis of teacher Ömer Alper Karasubaşı which was started with the advisement of Prof. Dr. Nail Yildırım and finished with Assoc. Prof. Dr. Uğur Akın. 
Öz: $\mathrm{Bu}$ araştırma, imam hatip lisesi öğrencilerinin bu okulları tercih sebepleri, hedefleri, okullarından beklentileri ve memnuniyetleri ile öğrenci ve imam hatip lisesi mezunlarının çeşitli konulardaki görüşlerini belirlemek amacıyla karma yöntemle yürütülmüştür. Araştırmada İmam Hatip Lisesi Öğrencilerinin Bu Okulları Tercih Nedenleri, Okuldan Beklentileri ve Memnuniyetleri Anketi, İmam Hatip Lisesi Öğrencilerinin Çeşitli Konulardaki Görüşleri Görüşme Formu ve İmam Hatip Lisesi Mezunlarına Göre İmam Hatip Liselerinin Dünü, Bugünü ve Yarını Anketi olmak üzere üç farklı veri toplama aracı öğrenci ve mezunlardan oluşan üç farklı çalışma grubuna uygulanmıştır. Verilerin analizinde frekans, ortalama ve yüzdelik gibi nicel betimsel analizler ile içerik analizi kullanılmıştır. 2017-2018 eğitim-öğretim yılında yürütülen araştırmanın sonuçlarına göre, öğrenciler imam hatip liselerini ailelerinin yönlendirmesi neticesinde tercih etmişlerdir. Bunun yanında, imam hatip liselerini tercih sebeplerine, istediği okula yerleşememe olarak ifade edilebilecek bir sebep eklenmiştir. Öğrencilerin beklentileri dinî bilgileri edinmeye yöneliktir. Aldığg eğitim sonrasında din görevlisi/ilahiyatçı olmak isteyen öğrenciler ise azınlıkta kalmıştır. Eğitim-öğretimin kalitesinin artırılması gerektiğini belirten öğrenciler, imkânları olsa bu okulu tercih etmeyeceklerini ve yönetim uygulamalarında çeşitli değişiklikler olması gerektiğini belirtmişlerdir. Öğrencilerin imam hatip lisesinde okumayı dinî/millî/manevî değerler çerçevesinde ifade ettikleri görülmüştür. Öğrenciler, imam hatip liselerinin dinî eğitim görmek anlamına geldiğini düşünmektedir. İmam hatipli olduklarını toplum içerisinde ifade edebildiklerini belirten öğrenciler, toplumun kendilerinden beklentilerinin olumlu yönde olduğunu düşünmekte, dinî/millî/manevî değerleri temsil eden şahsiyetleri örnek/ rehber olarak görmektedirler. Onlara göre, dünya sorunları içerisinde çözülmesi gereken öncelikli sorunlar dinî/ahlâkî sorunlar ile insanî sorunlardır. Mezunların kendi öğrencilik dönemlerini olumlu kavramlarla, günümüzü ise daha olumsuz kavramlarla ifade ettikleri, geleceğe dair daha ümitli oldukları görülmektedir.

Anahtar Kelimeler: Din eğitimi, İmam Hatip Liseleri, İmam Hatiplilik.

\section{$\&$}

Abstract: This research was carried out with a mixed method in order to determine Imam Hatip High Schools (IHHS) students's reasons behind their prefference of these schools, and their goals, expectations, and satisfaction regarding their schools, whilealso surveying the opinions of both; graduated and still studying students of imam high schools about various issues. Three data collection tools have been administred to three study groups. The data analyzed through 
quantitative descriptive analyses and content analysis. According to the results of the study which have been carried out in the 2017-2018 academic year, the students' choice of imam hatip high schools rest upon the directions of their parents. A new reason has been added to the reasons for selecting these schools which can be articulated as: "not being accepted to the desired school". The sum of students' expectations could be encapsulated as; getting religious knowledge. The number of the students intending to become a theologist/religious comissary is relatively low. The students state they wouldn't prefer to choose that school if it were possible. They have stated that especially administrative practices should be changed. Students have expresssed their perception about imam hatip high school and being a member within the framework of values such as religion, nation and morality. The students think the imam hatip high schools mean getting religious education. The students also stated that they have no reservation in expressing in public thata they are students in an imam hatip high schools and the society has positive expectations from them. They take the figures that representing religious/national/moral values as role models/guides. They argue that among the primary problems in the world to be solved are those of religious, moral and humanitarian ones. Graduates define the period of their time positively whereas they have a negative perception for today's imam hatips. Overall, they seem to be more hopeful for the future.

Keywords: Religious education, Imam Hatip Highschools, Being from Imam Hatips.

(The Extended Abstract is at the end of the article)

\section{Giriş}

Neredeyse tüm toplumların üzerinde uzlaştığı ender konulardan birinin eğitimin önemi ve gerekliliği olduğu ileri sürülebilir. Bununla birlikte, eğitimin içeriğinin ne olacağı, çocuklarımıza ne öğreteceğimiz ve onları nasıl eğiteceğimiz konusunda geniş çaplı bir mutabakat sağlamak görece daha zor görünmektedir. Yayla (2005), eğitimin sadece bir beceri edindirme çabası olarak görülmesinin eksik bir yaklaşım olacağını ifade etmektedir. Ona göre, bireye değerli olduğuna inanılan, insanı insan yapan değerler çerçevesinde bir eğitim sunulmalıdır. İnsanın eksik yetişmemesinin bir şartı olarak, onu ahlâkî yönden de yetiştirmek gereklidir. Benzer biçimde, son dönemlerde 2023 Eğitim Vizyonu (Milli 
Eğitim Bakanlığı [MEB], 2019) ile eğitimde çocuklara pozitif bilimleri anlayacağı, uygulayacağ 1 ve üreteceği becerilerin yanında bu becerileri insana yakışır biçimde, insanlığın hayrına kullanacağı temel değerleri kazandırmak öne çıkan bir politika haline gelmiştir. Bu noktada ortaya çıkan önemli sorulardan biri, bu temel insani değerlerin hangi kaynaktan alınacağı, hangi felsefe ya da felsefelerden besleneceği, ideolojik temelinin ne olacağıdır. Nüfusunun büyük çoğunluğu Müslüman olan ve dini, hayatının önemli bir parçası olarak gören Türkiye'de (bkz. Çarkoğlu ve Kalaycıŏglu, 2009) değerlerin kaynağı olarak ilk akla gelen unsurlardan biri İslam dinidir. Bu savı destekler ve örnekler biçimde, eğitimin değerlerden arınık olamayacağını savunan önemli düşünürlerden Topçu (2016), Türkiye'nin eğitimle ilgili en önemli sorunlarından birinin İslamî bir eğitim felsefesi meydana getirememesi olduğunu ileri sürmüştür. Türkiye'de, imam hatip liseleri kuruluşundan bu yana, ama özellikle son dönemlerde belirtilen anlamda değerlerin kazandırılacağı bir kaynak olarak görülmektedir. Her ne kadar lâiklik ve Cumhuriyet ekseninde yapılan tartışmalarda dinin Türkiye'deki konumuyla ilişkilendirilerek ciddi eleştirilere maruz kalsa da (Subaş1, 2004), toplumun önemli bir kesimi tarafindan bu okullara hem bilimle hem de değerlerle bütünleşmiş nesiller yetiştirmek adına önemli bir misyon yüklenmektedir.

Osmanlı Devleti döneminde dinî eğitim birçok farklı kurum tarafından yerine getirilmekteydi. İmam hatip liselerinin erken dönem örnekleri olarak kabul edilen Medresetü'l-Vaizîn ile Medresetü'l-Eimme ve'l-Hüteba ise özellikle din görevlisi yetiştirme vazifesini taşıyordu (Öcal, 2007). Cumhuriyetin ilanı ile birlikte siyasî ve kültürel alanlarda yapılan reformların sonucu olarak medreselerin 3 Mart 1924'te kabul edilen Tevhid-i Tedrisat Kanunu ile Maarif Vekaleti'ne devredilmesi kararlaştırılmıştır. Ancak dönemin Maarif Vekili Hüseyin Vasıf tarafından 11 Mart 1924 tarihinde medreselerin kapatılmasını emreden bir genelge ilgili makamlara gönderilmiştir. Bu kurumun yerine imam hatip mektepleri açılmıştır (Öcal, 2015, 87-88). İmam hatip mektebi olarak açıldığı 1924 yılında bu okullarda okuyup mezun olanlara herhangi bir imkânın sunulmamış olması ve benzer bir takım uygulamalar sonucunda, bu okullar uzun ömürlü olamamışlardır (Ergin, 1977: 2125; Gökaçtı, 2005: 143-146; Öcal, 2015: 138-139). Cumhuriyet öncesi dönemde medrese, mektep, tekke ve zaviye gibi kurumlar aracılığıyla dinî bilgileri edinme imkânı bulan insanlar, bu eğitim kurumlarının ilgası veya okullardan din derslerinin kaldırılmasının sonucunda dinî eğitim ihtiyaçlarını gidermek için yeterli imkân bulamamışlardır. 1930'lu yıllardan itibaren, örgün ve yaygın eğitim sistemi içerisinde din eğitiminin yer almaması, toplumsal ihtiyaç ve yozlaşma da dikkate alınarak (Öcal, 1994: 47), 18 yıl gibi 
uzun bir aradan sonra 1948 yılında kurs olarak açılan bu kurumların, büyük bir ilgi ile karşılaşmasına sebep olmuştur. Sonrasında imam hatip okulu olarak adlandırılmış ve yaygınlaştırılmıştır. Açılan imam hatip kurumlarına halk büyük bir teveccüh göstermiş, sadece din görevlisi olmak için değil, yıllardır imkân bulamadığı dinî eğitim ihtiyacını gidermek için de bu okulları tercih etmiştir.

Takip eden yıllarda, imam hatip liselerinin okul ve öğrenci sayılarında hızlı artışlar olmuştur. Ancak, askerî müdahaleler sonucunda kesintiye uğrayan demokrasi ile birlikte imam hatip kurumlarındaki olumlu gelişmeler de duraksama göstermiştir (Öcal, 2007). 1997 y1lında yaşanan ve medya, asker, sermaye baskısı sonucu açığa çıkan (Akıncı, 2013; Doğan, 2017; Ertem, 2018; Yüksel, 2012), "dışlayıcı laikliğin" yansıması olan 28 Şubat sürecinin olumsuz etkisi ile birlikte bu okulların ve okullara kayıt olan öğrencilerin sayısında da azalma olmuştur. Ancak yaşanan bu durum uzun sürmemiş, ülkede şekillenen siyasi tablonun da etkisi ile birkaç yıl içinde imam hatip liselerinin hem okul hem de öğrenci sayılarında niceliksel artışlar meydana gelmiştir (Öcal, 2007).

Türk eğitim sistemi içerisinde yer almaya başladığı günlerden itibaren, olumlu-olumsuz tartışmalara konu edilen imam hatip liseleri, içinde bulunduğu dönemin siyasî, içtimaî şartları sonucunda inişli-çıkışlı bir seyir izlemiştir. Uzun yıllar siyasi, toplumsal tartışmaların bir parçası olarak, çocuklarını imam hatip lisesine gönderen-göndermeyen tüm vatandaşların bu okullar etrafında yapılan tartışmalardan bir şekilde haberdar olduğu ve beyan edecek bir fikrinin olduğu söylenebilir. Günümüzde, niceliksel olarak Cumhuriyet döneminin en yüksek, okul ve öğrenci sayılarına ulaştığı görülen imam hatip liselerinin geçirdiği tarihsel iniş-çıkışlar dikkate alındığında içinde bulunulan dönemi bir "yükseliş" olarak isimlendirmek yanlış olmayacaktır. Engellerinden kurtulan ve "hâkim rüzgarlar"1 arkasına alan imam hatip liseleri hakkında ilgili-ilgisiz birçok taraf görüşlerini beyan ederken, öğrencileri ve mezunlarının bu okullara ilişkin çeşitli konulardaki görüşlerinin tespit edilmesi imam hatip liselerine ilişkin gerçekçi bir betimleme yapabilmek adına önemlidir.

Bu konuda yapılan araştırmalara bakıldığında, bu okulların dini bilgileri daha iyi öğrenme arzusuyla (Cebeci, 1995) ve öğrencilerin kendi istekleriyle (Aşlamac1, 2017; Ateş, 2016; Çakır, Bozan ve Talu, 2004; A. Doğan, 2006; Karateke, 2010; Korkmaz, 2013; Özensel ve Aydemir, 2016) tercih edildiğini gösteren çalışmalar bulunduğu görülmektedir. Bununla birlikte, Ortaöğretime geçişte uygulanan farklı yerleştirme sistemilerinin etkisiyle, öğrencilerin bir kısmının "ortaokuldan sonra sistemin yöneltmesi” sebebiyle istek dışı, başka bir kısmı- 
nın ise "puanının bu okula yeterli olması" sebebiyle bu okulu tercih etmek zorunda kaldıklarını gösteren araştırmalar (Aşlamacı, 2017; Görmez ve Coşkun, 2015) da mevcuttur. İmam hatip liselerine yönelik öğrenci beklentilerinin, kaliteli eğitim (A. Doğan, 2006), dini bilgileri daha iyi öğrenmek (Ateş, 2016; Karateke, 2010) olduğunu ortaya koyan çalışmalar da vardır. Bunların yanı sıra, öğrencilerin meslek ve kültür dersleri öğretmenlerine yönelik beklentilerini, öğrencilerin öğretmenlere yönelik tutumları üzerinden açıklamış çalışmalar da bulunmaktadır. Öğrencilerin memnuniyetlerine yönelik olarak ise, öğrencilerin büyük oranda bu okullardan memnun olduklarını ortaya koyan çalışmalar (Akdoğan, 1994; Arpacı ve Yıldırım, 2014; Çakır ve diğerleri, 2004) ve öğrencilerin memnuniyet düzeylerinin önceki yıllara nazaran gerilediğini gösteren çalışmalar (Aşlamacı, 2017; Korkmaz, 2013) bulunmaktadır. Günümüz imam hatip liselerinde, 2010 yılı öncesine göre, öğrenci sayısında yaklaşık iki buçuk, okul sayısında ise yaklaşık dört kat artış olmasına rağmen, öğrencilerin tercih, beklenti ve memnuniyetleri hakkında yakın dönemde yapılmış yeterli çalışmaya rastlanılmamış olması, ilgili literatürde bir boşluk olarak görülmektedir.

Literatürde "imam hatiplilik" kavramı üzerine yapılmış bazı çalışmalar bulunmaktadır. Bu çalışmalarda genel olarak ya kuramsal tartışmalar yürütülmüş ya da öğrenci haricindeki kişiler üzerinden araştırmalar yapılarak imam hatipliliğin ne olduğu tanımlanmaya çalışılmıştır. Öğrencilerin bu kavram hakkındaki düşünceleri üzerinden yapılmış olan çalışmaların sayısı, tüm bu çalışmaların az bir kısmını oluşturmaktadır. Yapılan çalışmalar ise (Aşlamacı, 2017; Çakır ve diğerleri, 2004; A. Doğan, 2006; Karateke, 2010) bu kimliği tanımlama gayretinin dışında, bir yönüyle tanıtma çabası içerisinde, farklı yönlerden ele almışlardır. Bunların yanı sıra, öğrencilerin imam hatiplilik hakkındaki düşüncelerini ortaya koymaya yönelik çalışmalar da bulunmaktadır (Dolmacı, 2018; Özensel ve Aydemir, 2016). İmam hatip liselerinden mezun olmuş kişilerin kendi öğrencilik yıllarındaki okulları ile günümüz imam hatip liseleri arasındaki değerlendirmelerini ve bu okulların geleceğine dair düşüncelerini belirlemek, imam hatip liselerine yüklenen ve resmî olmayan misyonu anlamak açısından önem arz etmektedir. Bununla birlikte geçmiş dönemlerde bu okullardan mezun olmuş kişilerin, okudukları okulun hayatlarına etkileri ve bu okullarda aldıkları eğitimin beklentilerini karşılama düzeyi hakkındaki görüşleri, verilen eğitimin niteliği hakkında fikir vermesi açısından önemli görülmektedir. Yapılan literatür taramalarında, imam hatip lisesi mezunlarının bu okulların geleceğine dair görüşlerini kısmen ortaya koyan bir çalışma (Çakır ve diğerleri, 2004) görülmüştür. Ancak imam hatip lisesi mezunlarının bahsi geçen diğer konular hak- 
kındaki düşüncelerini ortaya koyacak çalışmalar noktasında literatürde boşluk olduğu görülmektedir.

$\mathrm{Bu}$ araştırmanın amacı, imam hatip lisesi öğrencileri ve imam hatip lisesi mezunlarının imam hatip liselerine ve imam hatip liseli olmaya ilişkin çeşitli konulardaki görüşlerini belirlemektir. Bu amaç çerçevesinde şu sorulara cevap aranmıştır:

1. İmam hatip lisesi öğrencilerinin bu okulları tercih etmelerinin sebepleri nelerdir?

2. İmam hatip lisesi öğrencileri okullarından ne beklemektedir?

3. İmam hatip lisesi öğrencilerinin beklentilerinin karşılanmasına yönelik memnuniyet düzeyleri nedir?

4. İmam hatip lisesi öğrencilerinin okullarında gerçekleştirmek istedikleri değişiklikler nelerdir?

5. İmam hatip lisesinde okuyan öğrencilerin imam hatip liselerine ilişkin çeşitli konulardaki görüşleri nelerdir?

6. İmam hatip lisesinden mezun olanların bu okulları tercih etme sebepleri nelerdir ve bu okulları tercih etmeye yönelik şu anki eğilimleri nasıldır?

7. İmam hatip lisesinden mezun olanların, imam hatip liselerinin geçmişteki, şimdiki ve gelecekteki durumuna ilişkin görüşleri nelerdir?

8. İmam hatip lisesi mezunlarının bu okullarda gerçekleştirmek istedikleri değişiklikler nelerdir?

\section{Yöntem}

$\mathrm{Bu}$ araştırma, hem nicel hem de nitel araştırma yöntemlerinin uygulanmasını esas alan karma yöntem ile yürütülmüştür. Araştırma süreci kısmen karma eşzamanlı eşit statülü olarak tasarlanmıştır. Nicel ve nitel sürecin eşzamanlı olarak yürütülmesine ve araştırma içerisinde eşit ağırlığa sahip olmasına dayanan kısmen karma eşzamanlı eşit statülü tasarımda nicel ve nitel veriler analiz edilene kadar karıştırılmazlar (Baki ve Gökçek, 2012). Araştırmadan elde edilen verilerin yorum aşamasında birleştirilmesi hedeflendiği için kısmen karma, zaman verimliliğini artıracağ düşünüldüğü için eşzamanlı, nicel ve nitel bileşenlerin eşit ağırlıkta olması öngörüldüğü için ise eşit statülü olmasına karar verilmiştir. Araştırmanın nicel sürecinde, katılımcıların içinde bulundukları şartların ortaya koyulabilmesini sağlaması ve bu şartlar hakkındaki düşüncelerinin belirlenmesine yönelik olması sebebiyle nicel araştırma desenlerinden tarama modeli kullanılmıştır (Büyüköztürk, Çakmak, Akgün, Karadeniz ve Demirel, 2010: 231; 
Karasar, 2012: 77). Nitel süreçte katılımcıların birer durum olarak ele alındığı çoklu durum deseni işe koşulmuştur.

\section{Çalışma Grubu}

Araştırmanın nicel ve nitel kısımlarında öğrenci ve mezunlardan veri toplamak üzere üç farklı çalışma grubu belirlenmiştir. Birinci çalışma grubunda 20172018 eğitim-öğretim yılında Tokat Anadolu İmam Hatip Lisesi'nde kayıtlı bulunan 802 öğrencilik evrenden seçilen 254 öğrenci yer almaktadır. Katılımcılar, okulları hakkında daha fazla deneyime sahip olmaları sebebiyle $10(\mathrm{n}=61), 11$ $(n=89)$ ve 12. sınıf $(n=104)$ öğrencileri içerisinden basit seçkisiz örnekleme yoluyla belirlenmiştir. Öğrencilerin 23'ü kız, 231'i erkektir. Öğrencilerden nitel veri toplamak üzere belirlenen ikinci çalışma grubu yukarıda tanımlanan 802 kişilik evrenden maksimum çeşitlilik yöntemiyle seçilen 28 öğrenciden oluşmaktadır. Bu öğrencilerin 5'i kız, 23'ü erkektir. 7'si 10. sınıfta, 10'u 11. sınıfta, 11'i 12. sınıfta okumaktadır. Maksimum çeşitlilik örnekleme, evrende bulunan farklı grupların çeşitliliğinin örnekleme olabildiğince yansıtılmasıdır. Böylelikle evreni oluşturan çeşitlilik içerisindeki ortak ve farklı yönlerin ortaya çıkarılması hedeflenir (Büyüköztürk ve diğerleri, 2010, s. 90). Bu araştırmada da katılımcıların mümkün olduğunca farklı sınıf ve cinsiyetten olmasına özen gösterilmiştir. Ancak araştırmaya konu edilen okulun, 2018-2019 eğitim-öğretim yılından itibaren sadece erkek öğrencilere hizmet verecek olması sebebiyle, daha önce yeni kız öğrenci kaydı durdurulmuştur. Bu sebeple sadece 12. sınıfta kız öğrenci bulunmaktadır. Üçüncü çalışma grubu Türkiye'deki imam hatip lisesi mezunları arasından basit seçkisiz olarak ulaşılabilen 158 kişiden oluşmaktadır. Bunların 33'ü kadın, 125'i erkek, 136'sı evli, 22'si bekârdır. Mezunların 17'si lise, 95'i üniversite, 38'i yüksek lisans, 8'i doktora mezunudur. Mezun imam hatiplilerin 8'i din görevlisi iken 86'sı öğretmendir. Kalanlar ise polislikten doktorluğa farklı mesleklere mensuptur.

\section{Veri Toplama Araçları}

Araştırmanın amacına uygun olarak, her bir çalışma grubu için birer veri toplama aracı oluşturulmuştur. Araştırmanın geçerliği ve güvenirliğini sağlamak adına, veri toplama araçlarının geliştirilmesi aşamasında ilk olarak ilgili alanyazın taranmıştır. Tarama neticesinde anket ve görüşme formunu oluşturması planlanan bölümler ile soruların taslakları hazırlanmıştır. Oluşturulan taslaklar 
hakkında eğitim yönetimi ve denetimi alanında çalışmalar yapan bir öğretim üyesinin görüşüne başvurulmuştur. Alınan dönütler sonrasında yapılan düzenlemelerin ardından oluşturulan veri toplama araçlarıyla ön uygulama yapılmıştır. Ön uygulama neticesinde dil ve anlaşılırlık, amaca uygunluk kontrolleri yapılarak veri toplama araçlarına son şekli verilmiştir. Oluşturulan veri toplama araçlarına dair bilgiler ise aşağıda verilmiştir.

\section{İmam Hatip Lisesi Öğrencilerinin Bu Okulları Tercih Nedenleri, Okuldan Beklentileri ve Memnuniyetleri Anketi}

Öğrencilerin hedeflerini, imam hatip liselerinden beklentilerini ve bu okullardan memnuniyetlerini belirlemeye yönelik olarak "İmam Hatip Lisesi Öğrencilerinin Bu Okulları Tercih Nedenleri, Okuldan Beklentileri ve Memnuniyetleri Anketi” oluşturulmuştur. Bu veri toplama aracının geliştirilmesi esnasında, ağırlıklı olarak A. Doğan (2006) ve Karateke (2010) tarafindan yapılan araştırmalarda kullanılan ölçme araçları dikkate alınmıştır. Bu veri toplama aracı kişisel bilgiler, tercih etme sebepleri, beklentiler ve memnuniyet olmak üzere dört bölümden oluşmaktadır. Birinci bölüm öğrencilerin kişisel bilgilerini belirlemeye yönelik altı soru içermektedir. İkinci bölümde öğrencilerin bu okulu tercih etme sebeplerine dair 13 seçenek sunulan sorubulunmakta, öğrenciler bu kısımda birden fazla seçim yapabilmektedir. Üçüncü bölümde öğrencilerin imam hatip lisesinden beklentilerine dair yine çoklu seçim yapılabilecek altı seçenekli soru ile öğrencilerin meslek ve kültür dersleri öğretmenleri ile okul yönetiminden beklentilerine dair üç ayrı açık uçlu soru yer almaktadır. Dördüncü bölüm ise öğrencilerin bu okula yönelik memnuniyetlerini belirlemek için hazırlanmış 26 maddelik beşli Likert tipi bir anket, memnuniyete bağlı olarak yeniden imkân tanınsa bu okulu tercih edip etmeyeceklerine dair iki seçeneğin sunulduğu bir soru ve yetki tanınması halinde imam hatip liselerinde neleri değiştireceklerini belirlemeye yönelik olarak açık uçlu bir soru sorulmuştur.

\section{İmam Hatip Lisesi Öğrencilerinin Çeşitli Konulardaki Görüşleri Görüşme Formu}

Halen okumakta olan öğrencilere yöneltilen sorularla imam hatip lisesi öğrenci profilini belirlemeye hizmet etmesi amaçlanan "İmam Hatip Lisesi Öğrencilerinin Çeşitli Konulardaki Görüşleri Görüşme Formu” oluşturulmuştur. Bu veri toplama aracının geliştirilmesi esnasında, Türkiye İmam Hatipliler Vakf1 (TİMAV, 2014) ve A. Doğan (2006) tarafından yapılan araştırmalarda kullanılan veri toplama araçları dikkate alınmıştır. Oluşturulan veri toplama aracı ki- 
şisel bilgiler ve görüşme sorularının yer aldığı bölüm olmak üzere iki bölümden oluşmaktadır. Birinci bölüm öğrencilerin kişisel bilgilerini belirlemeye yönelik sorular içermektedir. İkinci bölümde öğrencilerin imam hatip liselerine ilişkin çeşitli konulardaki görüşlerini belirlemeye yönelik sekiz açık uçlu soru bulunmaktadır. Bu görüşme formundaki bir örnek soru şu şekildedir: "İmam-Hatipli olmak ne demektir? İmam Hatip Lisesinde okuyor olmanın, sınavlara hazırlanmaktan başka bir anlamı var mıdır? Lütfen belirtiniz."

\section{İmam Hatip Lisesi Mezunlarına Göre İmam Hatip Liselerinin Dünü, Bugünü ve Yarını Anketi}

Ayrıca imam hatip lisesi mezunlarının kendi öğrencilik dönemlerine ve günümüz imam hatip liselerine dair görüşlerini tespit etmek amaciyla "İmam Hatip Lisesi Mezunlarına Göre İmam Hatip Liselerinin Dünü, Bugünü ve Yarını Anketi” geliştirilmiştir. Bu veri toplama aracı kişisel bilgiler, tercih etme sebepleri, imam hatip liselerinin dünü, bugünü ve yarını hakkındaki görüşlerini değerlendirmeye yönelik soruların yer aldığı bölüm olmak üzere üç bölümden oluşmaktadır. Birinci bölüm imam hatip lisesi mezunlarının kişisel bilgilerini belirlemeye yönelik sorular içermektedir. İkinci bölümde imam hatip lisesi mezunlarının bu okulu tercih etme sebeplerine dair soru ve buna karşıllı olarak 11 seçenek yer almaktadır. Bu soruda birden fazla tercihin işaretlenmesine ve sunulan seçeneklerin dışında kalan farklı bir seçeneğin ifade edilmesine imkân tanınmıştır. Ayrıca bu bölümde yeniden imkân tanınsa bu okulu tercih edip etmeyeceklerine dair iki seçeneğin sunulduğu bir soru da yer almaktadır. Üçüncü bölümde yer alan ve mezunların, imam hatip liselerinin dünü, bugünü ve yarını hakkındaki görüşlerini belirlemek için hazırlanan beşli Likert tipi ankette bulunan ilk on iki madde imam hatip lisesi mezunlarının öğrenci oldukları döneme; sonraki on bir madde günümüz imam hatip liselerine ve son sekiz madde ise imam hatip liselerinin geleceğine yönelik yargılar taşımaktadır. Hazırlanan veri toplama arac1, İmam Hatipliler Derneği'ne (ÖNDER) üye 3 kişiye uygulanmış, alınan dönütler sonucunda veri toplama aracına son şekli verilmiştir.

\section{Veri Toplama Süreci}

Uygulanacak olan veri toplama araçları için Tokat Valiliği'nden 16.02.2018 tarih ve E.3316331 sayılı iznin alınmasının ardından, imam hatip lisesi öğrencilerine yönelik olarak hazırlanan iki veri toplama aracı, 07.05.2018 tarihinde saat 13.30-16.30 arasında yüz yüze uygulanmış ve o gün içerisinde alınmıştır. 
İmam hatip lisesi mezunlarına yönelik olarak hazırlanan veri toplama aracı bir çevrimiçi veri toplama uygulamasına (Google Forms) yüklenmiş, ilgili kişiler mezun dernekleri ve okul grupları ile iletişim neticesinde haberdar edilmiş ve buralardan veriler alınmıştır. Uygulamalar öncesinde, araştırmanın amacından bahsedilmiş, katılımcılar tarafından yöneltilen sorulara açıklık getirilmiştir. Ayrıca kişisel bilgilerin gizli tutulacağına dair gerekli bilgilendirmeler yapılmıştır.

\section{Verilerin Çözümlenmesi}

Veri toplama araçları ile toplanan nicel veriler SPSS 21 programına aktarılmıştır. Öğrenci ve mezunlara uygulanan veri toplama araçlarındaki, beşli Likert tipinde oluşturulmuş bölümlerden elde edilen görüşlerin aritmetik ortalamaları ile frekans ve yüzdeleri belirlenmiştir. Beşli Likert ölçeğine göre aritmetik ortalamaların değerlendirme aralıkları, "Kesinlikle katılmıyorum", "Katılmıorum", "Kararsızım”, Kat1lyyorum", “Kesinlikle kat1lyorum" maddelerinin 1'den 5'e kadar sayısal değer verilmesi ve aralıkların eşit kabul edilmesi sonucunda oluşturulmuştur. Buna göre, aritmetik ortalamalardan elde edilecek olan 1.00-1.80 arasındaki değer "kesinlikle katılmıyorum", 1.81-2.60 arasındaki değer "katılmıyorum", 2.61-3.40 arasındaki değer "kararsızım", 3.41-4.20 arasındaki değer "katılıyorum" ve 4.21-5.00 arasındaki değer ise "kesinlikle katılıyorum" olarak kabul edilmektedir. Ayrıca veri toplama aracında bulunan açık uçlu sorularla ilgili olarak içerik analizi yapılmıştır. İçerik analizinde takip edilen süreçlerden biri de, elde edilen veriler sonucunda araştırmacıda oluşan aşinalık neticesinde kategorilerin ortaya çıkmasıdır. Elde edilen içeriğin düzenlenmesi aşamasında kodlar ve temalardan faydalanılır. Görüşme tekniği ile elde edilen verilerin analizinde etkili olan içerik analizi sonucunda ortaya çıkan veriler yorumlanırken genel olarak frekans ve yüzde kullanılır (Büyüköztürk ve diğerleri, 2010: 273). İçerik analizi uygulamasında, elde edilen verilerin Microsoft Office Excel 2016 programına girişinin yapılarak kodlanması, kategoriler ve buna bağlı olarak temaların belirlenmesi, kategori ve temaların ilişkilendirilmesi, elde edilen bulgulara yönelik yorumlamaların yapılması adımları izlenmiştir. Farklı veri toplama araçlarından toplanan verilerin sağlandığı katılımcılar ayırt edilebilmesi bakımından farklı biçimlerde kodlanmıştır (örn. Ö1 [öğrenci 1], G1 [görüşülen öğrenci 1], M1 [mezun 1]). 


\section{Bulgular}

Bu başlık altında amaçlarla aynı sırada olacak biçimde; (1) öğrencilerin imam hatip lisesini tercih etme sebepleri, (2) öğrencilerin imam hatip lisesinden beklentileri, (3) öğrencilerin beklentilerinin karşılanmasına yönelik memnuniyetleri, (4) öğrencilerin okulla ilgili öngördügü değişiklikler, (5) öğrencilerin imam hatip ve imam hatiplilik kavramları hakkındaki düşünceleri, (6) imam hatip lisesi mezunlarının bu okulları tercih etme sebepleri, (7) imam hatip lisesi mezunlarının bu okulların dünü, bugünü ve yarını hakkındaki düşünceleri ve (8) imam hatip lisesi mezunlarının bu okullarda öngördüğü değişikliklere ilişkin bulgular aşağıda sunulmaktadır.

\section{1. Öğrencilerin İmam Hatip Lisesini Tercih Etme Sebepleri}

Öğrencilerin imam hatip liselerini tercih etme sebeplerini saptamak üzere birinci çalışma grubunda yer alan birden çok seçim yapabilecekleri bir tercih listesi sunulmuştur. Öğrencilerin verdikleri yanıtların frekans ve yüzdeleri Tablo 1'de verilmiştir.

\begin{tabular}{|c|c|c|}
\hline Tercih Sebepleri & $\mathrm{f}$ & $\%$ \\
\hline Ailem imam hatip lisesinde okumamı istediği için bu okula kaydoldum. & 131 & 51.57 \\
\hline Puanım planladığım okula yerleşmeye yetmediği için imam hatip lisesini tercih ettim. & 113 & 44.49 \\
\hline Lise öğreniminin yanında dinî eğitim verildiği için bu okulu tercih ettim. & 102 & 40.16 \\
\hline İmam hatip lisesinde okumayı kendim tercih ettim. & 98 & 38.58 \\
\hline İnançlarımı/ideallerimi yansıttığı için bu okulu tercih ettim. & 57 & 22.44 \\
\hline $\begin{array}{l}\text { Okuyan/mezun olan büyüklerim tarafından tavsiye edildiği için imam hatip lisesinde } \\
\text { okumaya karar verdim. }\end{array}$ & 50 & 19.68 \\
\hline Erkekler için en uygun okul olduğunu düşündüğümden bu okulu tercih ettim. & 36 & 14.17 \\
\hline İmam hatip lisesinin eğitim kalitesini duyduğum için bu okulu tercih ettim. & 24 & 9.45 \\
\hline Yakın arkadaşlarım imam hatip lisesinde okuduğu için burada okuyorum. & 20 & 7.87 \\
\hline Diğer & 19 & 7.48 \\
\hline İkametgâhıma yakın olduğu için bu okulu tercih ettim. & 18 & 7.09 \\
\hline Kızlar için en uygun okul olduğunu düşündüğümden bu okulu tercih ettim. & 14 & 5.51 \\
\hline $\begin{array}{l}\text { İmam hatip lisesinde okumak diğer okullara göre daha masrafsız olduğu için bu okulda } \\
\text { okuyorum. }\end{array}$ & 14 & 5.51 \\
\hline
\end{tabular}

Tablo 1'de görüldüğü gibi, öğrencilerin imam hatip liselerini tercih etmesinde öne çıkan ilk üç sebep, aile isteği (\%51.57), hedeflediği okula yerleşememek (\%44.49) ve bu okulun dinî eğitim vermesi (\%40.16) olarak karşımıza çıkmaktadır. Bu okulu kendisi seçenlerin oranı \%35.58 iken inanç ve ideallerini yansıttığı için bu okulu tercih ettiğini söyleyenlerin oranı ise \%22.44 olarak gerçekleşmiştir. 


\section{2. Öğrencilerin İmam Hatip Lisesinden Beklentileri}

İmam hatip lisesinden beklentilerini belirlemek üzere öğrencilere yine çoklu seçim yapabilecekleri bir liste sunulmuştur. Öğrencilerin seçimlerine ilişkin frekans ve yüzde değerleri Tablo 2'de sunulmuştur.

Tablo 2: Öğrencilerin İmam Hatip Lisesinden Beklentileri

\begin{tabular}{lcc}
\hline Beklentiler & $\mathrm{f}$ & $\%$ \\
\hline $\begin{array}{l}\text { İmam hatip lisesinde okuyup, dinî bilgileri öğrendikten sonra din görevliliği dışında } \\
\text { bir meslek sahibi olmak istiyorum. }\end{array}$ & 144 & 56.69 \\
\hline Lise eğitimimi güvenli, huzurlu bir ortamda geçirmek istiyorum. & 109 & 42.91 \\
\hline Lise eğitiminin yanında temel dinî bilgilerimi almak istiyorum. & 104 & 40.94 \\
\hline Kaliteli bir lise eğitimi almak istiyorum. & 97 & 38.19 \\
\hline İmam hatip lisesinde öğrenim görüp din görevlisi/ilahiyatçılmak istiyorum. & 44 & 17.32 \\
\hline Diğer & 37 & 14.57 \\
\hline
\end{tabular}

Tablo 2'de görüldüğü gibi, bu okulda dinî bilgileri edinmek isteyen ancak sonrasında din görevlisi olmak istemeyen öğrencilerin oranı (\%56.69) ile din görevlisi olmak için bu okulu tercih ettiğini beyan edenlerin oranı (\%17.32) arasında dikkate değer bir fark görülmektedir. Güvenli, huzurlu bir ortamda temel dini bilgileri öğrenmek ve kaliteli bir eğitim almak yönündeki beklentiler öne çıkmaktadır.

Araştırmaya katılan öğrencilere meslek dersleri, kültür dersleri öğretmenleri ile okul yönetiminden beklentilerinin neler olduğu üç ayrı açık uçlu soru ile sorulmuş, alınan cevaplar içerik analizi ile incelenmiştir. İçerik analizi sonuçlarına göre öğrencilerin hem meslek hem de kültür dersleri öğretmenlerinden beklentileri; "eğitim-öğretimin kalitesinin artırılmasına yönelik beklentiler" $\left(\mathrm{f}_{\text {meslek }}=73 ; \mathrm{f}_{\text {kültuir }}=98\right)$, "sınıf yönetimine yönelik beklentiler" $\left(\mathrm{f}_{\text {meslek }}=59 ; \mathrm{f}_{\text {kül- }}\right.$ tür $=30$ ), "ders geçmeye yönelik beklentiler" ( $f_{\text {meslek }}=35 ; f_{\text {kütlür }}=17$ ) ve "beklentisi olmadığını belirtenler" ( $f_{\text {meslek }}=13 ; f_{\text {küttür }}=14$ ) temadalarından oluşmaktadır. Öğrenciler meslek dersleri öğretmenlerine ilişkin ayrıca "mesleğe yönelik beklentiler"ini ( $\mathrm{f}=31$ ) ifade etmiştir. Bu temaları oluşturan kodlanmış görüşlerden öne çıkan beklentiler ise "derslerin daha etkili anlatılması" ( $\left.\mathrm{f}_{\text {meslek }}=56 ; \mathrm{f}_{\text {kültlür }}=53\right)$, "öğrenciyle sağlıklı iletişim kurulması”dır ( $\left.f_{\text {meslek }}=17 ; f_{\text {kültür }}=24\right)$. Öğrenciye "adaletli davranılması" ( $\mathrm{f}=17)$ ise meslek dersleri öğretmenlerinden bir beklenti olarak öne çıkmaktadır. Öğrencilerin okul yönetiminden beklentileri ise "adaletli yönetim” (f=133), "özgürlükçü disiplin uygulamaları" ( $\mathrm{f}=68)$, "sosyal etkinlikler" ( $\mathrm{f}=10)$ temalarında yoğunlaşmaktadır. 


\section{3. Öğrencilerin Beklentilerinin Karşılanmasına Yönelik Memnuniyetleri}

Öğrencilerin okullarından memnuniyetlerini belirlemek üzere 26 maddelik Likert tipi bir anket uygulanmıştır. Anketin genelini yansıtan birinci maddesine (imam hatip lisesinde gördüğüm eğitim-öğretimden dolayı memnunum) öğrencilerin verdikleri yanıtların ortalaması "kararsızım" düzeyindedir $(\overline{\mathrm{X}}=2.74)$. Bu soruya verilen olumlu cevapların (katıliyorum + kesinlikle katıliyorum) toplam1 \%31.49 olarak gerçekleşmiştir. Diğer bir ifadeyle öğrencilerin \%68.51’i imam hatip lisesinde okumaktan dolayı ya memnun değildir ya da bu konuda kararsızdır. Öğrencilerin görüşleri içerisinde aritmetik ortalaması en yüksek ilk üç madde sırasıyla "okulun temizlik konusunda eksiklikleri vardır" ( $\bar{X}=3.67)$, "bazı arkadaşlar, sürekli olarak olumsuz davranışlarla canımı sıkar” ( $\overline{\mathrm{X}}=3.52)$ ve "okuldan çıkmak için sık sık saate bakarım" ( $\overline{\mathrm{X}}=3.44)$ olmuştur. Ortalaması en düşük ilk üç madde ise sırasıyla "okulumuzda ödüllendirmede ve cezalandırmada adil davranılır" ( $\bar{X}=1.86)$, “okulumuzun fizikî yapısı kaliteli bir eğitim için yeterlidir" ( $\overline{\mathrm{X}}=1.90)$ ve "okulumuzda öğrenci beklentilerine önem verilir" $(\bar{X}=2.29)$ olmuştur. Öğrencilere, yine memnuniyetlerini saptamak üzere, anketin yanında tekrar tercih şansları olsa imam hatip liselerini seçip seçmeyecekleri sorulmuştur. Öğrencilerin \%73.2'si ( $\mathrm{f}=187$ ) “bugün yeniden imam hatip lisesine gelmezdim" seçeneğini tercih etmiştir.

\section{4. Öğrencilerin Okulla İlgili Öngördüğü Değişiklikler}

Araştırma kapsamında cevap aranan diğer soru imam hatip lisesi öğrencilerinin okullarında gerçekleştirmek istedikleri değişikliklerin neler olduğudur. Bu soruya dair öğrencilerin görüşleri alınmış, soruya verilen cevaplar içerik analizi ile incelenmiştir. İçerik analizi sonuçlarına göre, öğrencilerin imam hatip lisesinde öngördüğü değişiklikler; "yönetim uygulamaları ile ilgili değişiklikler" (f=134), "disiplin ile ilgili değişiklikler" ( $\mathrm{f}=68)$, "öğretmenler ile ilgili değişiklikler" (f=55), "sistem ile ilgili değişiklikler" ( $\mathrm{f}=40$ ), "eğitim-öğretim ile ilgili değişiklikler" (f=32), "fizikî şartlar ile ilgili değişiklikler" (f=30) ve "sosyal/ sportif faaliyetler ile ilgili değişiklikler" ( $\mathrm{f}=15$ ) olarak 7 temada ifade edilmiştir. $\mathrm{Bu}$ temaları oluşturan kodlanmış görüşlerden öne çıkanlarsa "öğretmen kadrosunu değiştirmek" ( $\mathrm{f}=51$ ), "okul yönetimini değiştirmek" ( $\mathrm{f}=48$ ) ve "adaleti sağlamak" ( $\mathrm{f}=41)$ olarak belirlenmiştir. 


\section{5. Öğrencilerin İmam Hatip Liselerine İlişkin Çeşitli Konulardaki Düşünceleri}

Öğrencilerin imam hatip liselerine ilişkin çeşitli konulardaki görüşlerini irdelemek üzere araştırmanın 28 kişilik ikinci çalışma grubuna 8 soruluk görüşme formu uygulanmış, alınan cevaplar içerik analizi ile analiz edilmiştir. Analiz sonuçları soru sırasına göre şu şekildedir:

1. Öğrencilere ilk olarak "sizce imam hatip lisesi ne demektir?" sorusu sorulmuştur. Analizler sonucunda öğrencilerin büyük çoğunluğunun imam hatip liselerine olumlu bir anlam yüklediği görülmüştür ( $\mathrm{f}=21)$. İmam hatip liselerine özel bir anlam yükleyen öğrencilerin öne çıkardıkları kavramlarsa "din eğitimi görmek" ( $\mathrm{f}=10)$ ve "şuur sahibi olmak" $(\mathrm{f}=4)$ olmuştur.

2. Öğrenciler "imam hatip liselerinin temel görevinin ne olduğunu düşünüyorsunuz?" sorusuna, çeşitli beceriler edindirmek $(\mathrm{f}=21)$, "manevi değerleri kazandırmak" (18) ve "hayallerimizi yıkmak" ( $\mathrm{f}=2$ ) biçiminde temaland1rılan cevaplar vermişlerdir. Bu temaların öne çıkan kodlanmış görüşleri ise "dini bilgileri öğretmek" ( $\mathrm{f}=17)$, "şuurlu nesiller yetiştirmek" ( $\mathrm{f}=7)$ ve "ahlaki değerleri kazandırmak" ( $\mathrm{f}=6$ ) olmuştur.

3. Öğrencilerin çoğunluğu imam hatipli olmanın özel bir anlamı olduğunu düşünürken ( $\mathrm{f}=16)$ "imam hatipli olma" kavramına özel bir anlam yüklemeyen öğrenciler de vardır ( $\mathrm{f}=10)$. İmam hatipli olma kavramına özel bir anlam yükleyen öğrencilerin öne çıkardığı görüş ise "maneviyat kazanmak" olmuştur.

4. Öğrencilerin büyük çoğunluğu "bulunduğunuz ortamlarda imam hatip liseli olduğunuzu rahatlıkla ifade edebiliyor musunuz?" sorusuna olumlu yanıt vermiş ve olumlu reaksiyon aldıklarını ifade etmiştir ( $\mathrm{f}=21)$. Bunun yanında imam hatipli olduklarını söyleyemediklerini, olumsuz reaksiyon aldıklarını/algıladıklarını beyan eden katılımcılar da vardır $(\mathrm{f}=10)$.

5. Öğrencilerin büyük çoğunluğu "sizce toplumun, imam hatipli öğrencilerden beklentileri nelerdir?" sorusuna olumlu anlam içeren beklentiler olduğu yönünde cevaplar vermiştir $(\mathrm{f}=24)$. Bu tema altında öne çıkan beklentiler; örnek olmak ( $\mathrm{f}=7$ ), ahlaklı olmak ( $\mathrm{f}=5)$, din görevlisi olmak $(\mathrm{f}=3)$ ve dürüst olmak ( $\mathrm{f}=2)$ şeklide belirlenmiştir.

6. Öğrencilere "kendinize rehber/örnek edindiğiniz kişiler kimlerdir?” sorusu yöneltilmiştir. Burada öğrenci görüşleri oldukça çeşitlenmiş, dini şahsi- 
yetler $(\mathrm{f}=12)$, aile bireyleri $(\mathrm{f}=12)$, siyasi şahsiyetler ve devlet adamları $(\mathrm{f}=11)$, yakın çevre $(\mathrm{f}=6)$, kahraman olarak addedilenler $(\mathrm{f}=5)$ ve fikir adamları $(f=4)$ tekrarlayan görüşleri içeren temalar olarak ortaya çıkmıştır. Dini şahsiyetlerde Hz. Muhammed (SAV) $(\mathrm{f}=4)$, aile bireylerinde baba $(\mathrm{f}=$ 4), siyasi şahsiyetleri ve devlet adamlarında Alparslan Türkeş ve Muhsin Yazıcıŏlu ( $\mathrm{f}=3$ ), yakın çevrede öğretmenler $(\mathrm{f}=2)$, kahraman olarak addedilenlerde Ömer Halis Demir ve Fethi Sekin ( $\mathrm{f}=2$ ), fikir adamlarında Ziya Gökalp ( $\mathrm{f}=2$ ) en çok tekrarlanan örnek şahsiyetler olarak ifade edilmiştir.

7. İmam hatip lisesi öğrencilerine "imkânınız olsa, şu an dünyanın hangi sorunlarına çözüm üretmek isterdiniz?" sorusu yöneltilmiş, katlımıcılar dini/ ahlaki sorunlar $(f=19)$ ve insani sorunları $(f=18)$ öne çıkarmışlardır. Bunu ekonomik sorular $(\mathrm{f}=10)$ ve çevre sorunları $(\mathrm{f}=8)$ izlemektedir. Bu temalarda en çok tekrarlanan sorunlar ise savaş ( $\mathrm{f}=5)$, zulüm $(\mathrm{f}=5)$, açlık $(\mathrm{f}=4)$, adaletsizlik ( $\mathrm{f}=4$ ) ve ahlaksızlık ( $\mathrm{f}=4$ ) olmuştur.

8. Son olarak öğrencilere "İslâm dünyasının içinde bulunduğu durum hakkındaki düşünceleriniz nelerdir?" sorusu yöneltilmiş̧ir. Katılımcıların çoğu bu konuda olumsuz düşünceler beyan ederken ( $\mathrm{f}=16$ ) olumlu görüşler azınlıktadır ( $\mathrm{f}=3)$. Olumsuz temada açık ara öne çıkan görüş "Müslümanların niteliğinin düşük olması" olarak ifade edilmiştir ( $\mathrm{f}=8)$. Bu görüşü bir "İslam birliği kurulamaması" izlemiştir ( $\mathrm{f}=3$ ). Olumlu görüş bildirenler ise "umutlu" olduklarını ifade etmişlerdir ( $\mathrm{f}=2$ ). Öğrencilerden biri bu görüşünü "umutluyum, bir gün yeniden bu dünyaya nizamı, adaleti getireceğiz (G18)" diyerek ifade etmiştir.

\section{6. İmam Hatip Lisesi Mezunlarının Bu Okulları Tercih Etme Sebepleri}

Araştırma kapsamında yanıt aranan "imam hatip lisesinden mezun olanların bu okulları tercih etme sebepleri nelerdir ve bu okulları tercih etmeye yönelik şu anki eğilimleri nasıldır?” sorusuna dair üçüncü çalışma grubunda yer alan imam hatip lisesinden mezun olmuş katılımcıların görüşleri alınmış, tercih etme sebeplerine ilişkin veriler Tablo 3'te betimlenmiştir.

\begin{tabular}{lll}
\hline Tablo 3: Mezunların İmam Hatip Lisesini Tercih Etme Sebepleri & & \\
\hline Tercih Sebepleri & $\mathrm{f}$ & $\%$ \\
\hline Ailem imam hatip lisesinde okumamı istediği için bu okula kaydoldum. & 69 & 29.36 \\
\hline İmam hatip lisesinde okumayı kendim tercih ettim. & 63 & 26.81 \\
\hline İnançlarımı/ideallerimi yansıttığı için bu okulu tercih ettim. & 48 & 20.43 \\
\hline Büyüklerim tarafından tavsiye edildiği için imam hatip lisesinde okumaya karar verdim. & 30 & 12.77 \\
\hline İmam hatip lisesinin eğitim kalitesini duyduğum için bu okulu tercih ettim. & 10 & 4.26 \\
\hline
\end{tabular}




\begin{tabular}{lcc}
\hline Diğer & 5 & 2.13 \\
\hline $\begin{array}{l}\text { İmam hatip lisesinde okumak diğer okullara göre daha masrafsız olduğu için bu okulu } \\
\text { tercih ettim. }\end{array}$ & 3 & 1.28 \\
\hline Yakın arkadaşlarım imam hatip lisesinde okuduğu için bu okulu tercih ettim. & 3 & 1.28 \\
\hline Erkekler için en uygun okul olduğunu düşündüğümden bu okulu tercih ettim. & 2 & 0.85 \\
\hline Kızlar için en uygun okul olduğunu düşündüğ̈ümden bu okulu tercih ettim. & 1 & 0.43 \\
\hline İkametgâhıma yakın olduğu için bu okulu tercih ettim. & 1 & 0.43 \\
\hline
\end{tabular}

Tablo 3'teki verilerin oluşturulması sırasında, çalışma grubunda bulunan kişilerin imam hatip lisesini tercih etme sebebi olarak bir veya daha fazla tercihte bulunmalarına imkân tanınmıştır. Buna göre, kişilerin bu okulları tercih etmesinde öne çıkan üç sebep, aile isteği (\%29.36), kendi isteği (\%26.81) ve inanç ve ideallerini yansıtması (\%20.43) olarak karşımıza çıkmaktadır. İnanç ve ideallerini yansıttığg için bu okulu tercih ettiğini söyleyenlerin oranı imam hatip lisesi mezunu kişilerde \%20.43 iken, hali hazırda imam hatip lisesi öğrencisi olanlarda bu oran \%8.19'dur (bkz. Tablo 1).

Aynı araştırma sorusu kapsamında mezunlara imam hatip liseleri ile ilgili deneyim ve düşüncelerinden hareketle, tekrar tercih etmeleri gerekseydi bu okulları tercih edip etmeyeceklerine dair görüşleri sorulmuştur. Araştırmaya katılan 158 mezundan 152'si (\%96.20) yine imam hatip lisesini tercih ederdim cevabını vermişlerdir.

\section{7. İmam Hatip Lisesi Mezunlarının Bu Okulların Dünü, Bugünü ve Yarını Hakkındaki Düşünceleri}

Araştırma kapsamında, "imam hatip lisesinden mezun olanların, imam hatip liselerinin geçmişteki, şimdiki ve gelecekteki durumuna ilişkin görüşleri nelerdir?” sorusuna yanıt aranmış, katılımcıların görüşleri beşli Likert tipinde hazırlanmış anket sorularıyla alınmıştır. Mezunların, kendi öğrencilik dönemleri hakkındaki görüşleri içerisinde aritmetik ortalaması en yüksek ilk üç madde sırasıyla "imam hatip lisesinde gördüğüm eğitim-öğretimden dolayı memnunum" ( $\overline{\mathrm{X}}=4.49$, kesinlikle kat1lıyorum), "günümüzde İmam-Hatip Liseleri daha iyi fizikî şartlara sahiptir” ( $\overline{\mathrm{X}}=4.47$, kesinlikle katılıyorum) ve "öğrenci olduğum dönemde imam hatip lisesi öğretmenleri gayretliydi” ( $\bar{X}=4.23$, kesinlikle katılıyorum) olmuştur. Bunun yanında, mezunların kendi öğrencilik dönemleri hakkındaki görüşleri içerisinde aritmetik ortalaması en düşük ilk üç madde ise sırasıyla "imam hatip lisesinde okuduğumu söylemekten utanırdım" $(\overline{\mathrm{X}}=1.83$, katılmıyorum), "öğrenci olduğum dönemlerde medya genel olarak imam hatip liselerine destek veriyordu" ( $\mathrm{X}=1.92$, katılmıorum) ve "gelecekte dinî eğitim 
almak için İmam-Hatip Liselerine ihtiyaç kalmayacaktır" ( $\bar{X}=2.37$, katılmıyorum) olmuştur.

İmam hatip lisesi mezunlarının, günümüz imam hatip liseleri hakkındaki görüşleri içerisinde aritmetik ortalaması en yüksek ilk iki madde sırasıyla "günümüzde imam hatip liseleri daha iyi fizikî şartlara sahiptir" ( $\overline{\mathrm{X}}=4.47$, kesinlikle katılıyorum) ve "günümüzde imam hatip liselerinin öğrenci sayısının artmasına rağmen kalitesi düşmüştür" ( $\overline{\mathrm{X}}=3.94$, katılıyorum) olmuştur. Mezunların günümüz imam hatip liseleri hakkındaki görüşleri içerisinde ortalaması en düşük ilk üç madde ise "günümüzde şuurlu bir imam hatip nesli yetişmektedir" ( $\bar{X}=2.70$, kararsızım), "günümüzde imam hatip liseleri hiç olmadığı kadar siyasetle iç içe olmuştur" ( $\bar{X}=2.90$, kararsızım) ve "günümüz imam hatip liselerinin, dinî eğitim açısından diğer liselerden pek farkı kalmamıştır" ( $\bar{X}=2.90$, kararsızım) olmuştur.

İmam hatip liselerinin geleceği hakkındaki görüşler içerisinde ortalaması en yüksek ilk iki madde "imam hatip liseleri daima toplumsal birleştiricilik görevi üstlenmişlerdir" ( $\overline{\mathrm{X}}=4.08$, katıllyorum) ve "gelecek yıllarda imam hatip liselerinde daha kaliteli eğitim verileceğini düşünüyorum" ( $\bar{X}=3.76$, katılıyorum) olmuştur. Bunun yanında, mezunların gelecek hakkındaki görüşleri içerisinde ortalamas1 en düşük ilk iki madde "gelecekte dinî eğitim almak için imam hatip liselerine ihtiyaç kalmayacaktır" ( $\bar{X}=2.37$, katılmıorum) ve "önümüzdeki yıllarda imam hatip liselerine olan ilgi azalacaktır” ( $\overline{\mathrm{X}}=2.56$, katılmıyorum) olmuştur.

\section{8. İmam Hatip Lisesi Mezunlarının Bu Okullarda Öngördüğ̈̈ Değişiklikler}

Araştırma kapsamında katılımcılara "yetkiniz olsaydı imam hatip liselerinde neleri değiştirirdiniz?" sorusu yöneltilmiştir. Soruya verilen cevaplara ilişkin içerik analizi sonuçları göre, katılımcılar "eğitim-öğretimle ilgili değişiklikler" ( $\mathrm{f}=54)$, "öğretmenlerle ilgili değişiklikler" ( $\mathrm{f}=42$ ), "öğrencilerle ilgili değişiklikler" ( $\mathrm{f}=22)$, "yönetimle ilgili değişiklikler" ( $\mathrm{f}=20)$, "imam hatip liselerinin yaygınlaşmasıyla ilgili değişiklikler" ( $\mathrm{f}=12$ ) ve "disiplinle ilgili değişiklikler" $(\mathrm{f}=6)$ temalarında toplanan görüşler bildirmişlerdir. $\mathrm{Bu}$ temaların oluşturan görüşlerden en sık tekrarlananlarına göre mezunlar, müfredatın ( $\mathrm{f}=25)$ ve öğretmen kadrusunun ( $\mathrm{f}=24$ ) değişmesini ve imam hatip liselerinde şuur kazandıran bir eğitim verilmesini $(\mathrm{f}=22)$ istemektedir. Bir mezun bu konudaki görüşünü "cemaatlerin kandiramayacă̆ bilinçte eğitim ve ibadet alışkanlığ kazandlrllmasına çok önem verirdim (M2)" şeklinde ifade etmiştir. Bir başka mezun 
eğitim-öğretimle ilgili değişiklikler teması kapsamında "Biz kaymakam, hâkim olmayl hedefliyorduk genel olarak, ben banka müfettişi oldum. Oysaki bir sinemacl, tiyatro, güzel sanatlar, gazeteci vs. olma arzusu yoktu. Hayatın her yönüne insan yetiştiren bir okul olmalı imam hatip liseleri (M85) " diyerek görüşlerini dile getirmiştir.

\section{Tartışma}

\section{Öğrencilerin İmam Hatip Lisesini Tercih Etme Sebepleri}

Araştırmaya katılan imam hatip lisesi öğrencilerinin büyük çoğunluğu bu okulları ailelerinin yönlendirmesi neticesinde tercih etmişlerdir. Daha önce yapılmış araştırmalar (Aşlamac1, 2017; Ateş, 2016; A. Doğan, 2006; Karateke, 2010; Korkmaz, 2013; Özcan, 2010; Özensel ve Aydemir, 2016; Türkmen Gül, 1998; Ünal 2008; Ünlü, 1999), öğrencilerin imam hatip lisesini tercih etmelerinde en çok kendi isteklerinin ve aile isteğinin etkili olduğunu göstermiştir. Çakır ve diğerleri (2004) ile Karacoşkun (1994) tarafindan yapılan çalışmalar da öğrencilerin bu okulları kendi istekleri ile tercih ettiklerini göstermektedir. Cebeci (1995) ise, imam hatip lisesi öğrencilerinin bu okulları dini bilgileri daha iyi öğrenme arzusu içerisinde tercih ettiklerini belirtmiştir. Bu çalışmada ise, öğrencilerin imam hatip lisesini tercih etme sebeplerinin ilk beşinin aile etkisi, istediği okula yerleşememe, dinî eğitim verilmesi, öğrencinin kendi isteği, inanç/ideali yansıtması şeklinde sıralandığ görülmektedir. Buna göre araştırmadan elde edilen bulgular, bahsi geçen araştırmalarda elde edilen bulgulardan farklılaşarak, ögrencilerin bu okulları tercihlerinde aile yönlendirmesinin etkisini artırdığını ve istediği okula yerleşememe gibi yeni bir etkinin ortaya çıktığını göstermiştir. Kendi istekleri dişında (aile isteği, istediği okula yerleşememe) bir etki ile bu okullara kaydolan öğrencilerin, mevcut öğrencilerin üçte birinden fazlasını oluşturuyor olması önemlidir. Özellikle ortaöğretim kurumlarına öğrenci yerleştirmek amacıyla yapılan merkezî sınavlar neticesinde elde edilen puanların, öğrencilerin yerleşmeyi hedefledikleri okullara yetmemesi sonucunda zoraki olarak bu okullara yönelmelerine neden olduğunu gösteren sonuca ulaşılması, bu okullar üzerinde nicelik-nitelik dengesi çerçevesinde yapılan tartışmalara 1şık tutması açısından dikkate değerdir. Bu bulgu yorumlanırken, bu araştırmanın örneklemini oluşturan öğrencilerin tamamının Temel Eğitimden Ortaöğretime Geçiş (TEOG) sistemiyle yerleştirildiği unutulmamalıdır. TEOG’un oluşturduğu bu etki yeni ortaöğretime yerleştirme sistemi ile belli ölçüde k1- 
rılmıştır. Yeni yerleştirme sisteminde öğrenci tercihlerini etkileyen unsurların neler olduğu ileriki araştırmalarda ele alınabilir. Aşlamacı (2017) da TEOG ile yerleşen öğrenciler ile yaptığı araştırmasında, bazı öğrencilerin sistemin yönlendirmesi ve puan yetersizliği gibi sebeplerle bu okulu tercih etmek zorunda kaldıklarını ortaya koymuştur. Özdemir ve Karateke (2018) ise, bu okulların tercih edilmesinde aile isteğinin en etkili sebep olarak öne çıktığını belirtmekle beraber, öğrencilerin yaklaşık yarısının tercih sürecinde aileleriyle görüş ayrılığı yaşadığını ifade etmişlerdir. Ayrıca öğrencilerin çoğunluğunun sınav puanını öğrendikten sonra bu okulları tercih etmeye karar verdiklerini belirtmişlerdir. Aynı çalışmada, öğrencilerin yarıdan fazlasının ilk tercihinin imam hatip lisesi olmadığı, farklı lise türüne yerleşemedikleri için bu okula kaydoldukları sonucu ortaya çıkmıştır. Yine bu doğrultuda, Görmez ve Coşkun (2015) tarafından yapılan çalışma, öğrencilerin sistem tarafından tercih etmedikleri veya tercih etmek zorunda kaldıkları okullara yerleştirildiklerine dair bulguları ortaya koymuştur. Görmez ve Coşkun (2015), 2013-2014 eğitim-öğretim yılında uygulamaya konulan TEOG sistemi ile birlikte tüm öğrenci ve okul türlerinin tercih havuzuna dâhil edildiği yerleştirme sürecinin böyle bir etkiye sebep olduğunu belirtmişlerdir. Bu durum, sayıları hızla artan imam hatip liselerinin tercih havuzunda önemli bir yere sahip olmasını sağlamıştır. Ayrıca, sisteme dâhil olan öğrenci sayısının da artmış olmasıyla, tercih ve yerleştirme sürecinde istek dışı kurumlara yerleştirmeler meydana gelmiştir. Bu etkinin bir sonucu olarak, esas sebep olmasa da, sistem yönlendirmesinin öğrencilerin bu okulu tercihinde göz ardı edilemeyecek kadar önemli bir yere sahip olduğu görülmüştür. Belirtildiği gibi artık TEOG kaldırılmış, artık yeni bir ortaöğretime yerleştirme sistemi yürürlüğe konulmuştur. Yeni sistemin yerleştirme uygulamalarına ilişkin ilk gözlemler ve dönütler olumlu görünse de durumu görünümünü verilere dayalı olarak ortaya koyacak çalışmalara gereksinim duyulduğu değerlendirilmektedir. Bunun yanında, bir ideal veya inancı önceleyerek bu okulu tercih ettiğini belirten öğrencilerin azınlıkta kaldığı görülmektedir. Bu durum, "imam hatiplilik", "şuurlu gençlik", "dindar nesil”, "imam hatip nesli" gibi kavramlarla ifade edilen ve belirli bir ulvî amaç çerçevesinde, topluma hizmet bilinciyle hareket etmeyi salık veren "imam hatiplilik" şuuru hakkında düşündürücü bir sonuç olarak görülmektedir. 


\section{Öğrencilerin İmam Hatip Lisesinden Beklentileri}

Araştırmaya katılan imam hatip lisesi öğrencileri, bu okullardan dinî bilgileri edinmeyi beklemektedir. Karateke (2010) tarafından yapılan çalışmada ise, öğrenciler dinî bilgileri daha iyi öğrenmenin yanında, bunları uygulamaya dönük imkânlar beklediklerini belirtmişlerdir. Ateş (2016) imam hatip lisesi öğrencilerinin beklentilerini belirlemeye ilişkin çalışmasında, öğrencilerin dini bilgileri öğrenme beklentisi içinde olduğu sonucuna ulaşmıştır. Araştırma sonucunda ulaşılan bulguları destekler mahiyetteki bu çalışmaların yanı sıra, A. Doğan (2006) da, öğrencilerin bu okullardan beklentilerinin genel olarak kaliteli eğitim sunulması üzerine yoğunlaştığı sonucuna ulaşmıştır. Buna göre, öğrencilerin kaliteli eğitim beklentileri hem dinî/meslekî hem de genel eğitime yöneliktir. Bu noktada, bu okulları dinî bilgileri edinmekte bir araç olarak gören ve bu ihtiyacı karşılamak beklentisi içinde olanların oranının, din eğitiminin göz ardı edilemez bir ihtiyaç olduğunu gösterdiği söylenebilir. Din eğitimi almak için imam hatip lisesini tercih ettiğini belirten öğrencilerin oranı aynı zamanda, diğer ortaöğretim kurumlarında seçmeli dersler üzerinden genişletilmiş olan dinî içerikli derslere rağmen, bu okulların din eğitimi konusunda öncelikli bir yere sahip olduğunu göstermektedir. Hem katılımcı öğrencilerden hem de mezunlardan alınan veriler beraber değerlendirildiğinde, bireylerin din eğitimine yönelik taleplerini karşılamak için, imam hatip liselerini çoğunlukla alternatifsiz görmelerinin etkisiyle bu okullara yöneldikleri görülmektedir.

Araştırmadan elde edilen bir diğer önemli sonuç da, imam hatip lisesi öğrencileri içerisinde din görevlisi olmayı hedefleyenlerin azınlıkta olduğudur. 2000 öncesi çalışmalarda (örn. Türkmen Gül, 1998; Ünlü, 1999), bu okullardan mezun olduktan sonra din görevlisi olmak isteyenlerin, imam hatip lisesi öğrencilerinin en az yarısını oluşturduğu görülmektedir. Araştırma bu yönüyle önceki çalışmalardan farklılaşmıştır. İmam hatip lisesi mezunlarının meslek grupları, imam hatip lisesi öğrencilerinin din görevlisi olma konusundaki isteksizliği ve bu okuldan dinî bilgileri edinmeye yönelik beklentileri beraber değerlendirildiğinde, bu okullardan mezun olanların din görevlisi olma oranlarının düşük olması daha anlaşılır hâle gelmektedir. Bu durum, geçmişten günümüze, imam hatip lisesi öğrencilerinin bu okullarda gördükleri eğitimden sonra din görevlisi olmadıklarına yönelik yapılan eleştiriler açısından dikkate değerdir. Ancak, bu noktada din görevliliğinin meslek olarak seçilmemesinden ziyade, bu okulların din eğitimi konusunda alternatifsiz görülmelerinden hareketle bir değerlendirme yapılması daha kabul edilebilir görülmektedir. Bir başka deyişle, beklenti- 
leri dinî bilgileri edinmek olan öğrencilerden, sadece din görevlisi olmalarını beklemek ve bu yönde eleştiriler geliştirmek, bu konudaki tartışmaların yanlış bir zemin üzerine bina edildiğini düşündürmektedir.

İmam hatip lisesi öğrencileri meslek dersleri öğretmenlerinden eğitim-öğretimin kalitesinin artırılmasına dair beklenti içindedirler. Özellikle, meslek derslerinin yeterince etkili anlatılmadığı görüşünün öğrenciler arasında yaygın olduğu görülmektedir. Benzer durum kültür dersleri öğretmenlerinden beklentiler için de geçerlidir. Bunun yanında, eğitim-öğretimin kalitesinin artırılmasına yönelik beklenti daha yüksek orandadır. Her iki öğretmen grubuna yönelik beklentiler değerlendirildiğinde, öğrencilerin imam hatip lisesinde sunulan eğitim-öğretimin kalitesini yeterli görmedikleri anlaşılmaktadır. Aşlamacı (2017) çalışmasında, meslek dersi öğretim sürecinin imam hatip lisesi öğrencilerinin beklentilerine yeterince cevap veremediğini belirlemiştir. Karateke (2010) ise, imam hatip lisesi öğrencilerinin, meslek ve kültür dersleri öğretmenlerinden kendileri ile daha fazla ilgilenmeleri yönünde beklenti içerisinde olduklarını belirtmiştir. Bu yönüyle araştırma, daha önce yapılmış çalışmalarla aynı yönde sonuçlar ortaya koymuştur. Ayrıca öğrenciler, okul yönetimi tarafından adil yönetilmeyi beklemektedirler. Öğrencilerin, okul yönetiminin uygulamaları s1rasında, kişiler arasında yeterince adil davranılmadığı vurgusunu sıkça tekrarladıkları görülmüştür.

\section{Öğrencilerin Beklentilerinin Karşılanmasına Yönelik Memnuniyetleri}

İmam hatip lisesi öğrencileri genel olarak okul şartlarından memnun görünmemektedir. Öğrencilerin büyük kısmı yeniden liseye kayıt yaptıracak olsalar imam hatip lisesine gelmeyeceklerini ifade etmiştir. Bu sonuç, bu öğrencilerin okula olan aidiyetlerini yitirdikleri şeklinde de yorumlanabilir. Öğrencilerin, memnuniyet düzeylerini belirlemeye yönelik olarak kendilerine yöneltilen olumlu önermelerden hiçbirine katılmamış olmaları, olumsuz önermelere ise genel olarak katılmış olmaları bu kanaati kuvvetlendirmektedir. Aşlamacı (2017) tarafından yapılan araştırmada ise, imam hatip lisesi öğrencilerinin yarısının okullarından memnun olduğu sonucu elde edilmiştir. Bu konuda daha önce yapılmış olan çalışmaları dikkate alarak yaptığı incelemelerde Aşlamacı (2017), 28 Şubat süreci ve öncesinde \%80 üzerine ulaşacak kadar yüksek olan memnuniyet oranının, özellikle 2014 ve 2016 yıllarında yapılan çalışmalarda, dikkat çekici biçimde \%50-55'e kadar düştüğünü belirtmiştir. Aşlamacı tarafından belirtilen durumu destekler bir çalışma da Korkmaz (2013) tarafından yapı1- 
mıştır. Bu çalışmaya göre, okulundan memnun olduğunu belirten öğrenci oranı \%60.90'dır. Korkmaz (2013), öğrencilerin memnun olma durumlarını daha çok dinî eğitim alabilmeleri ile ilişkilendirdiklerini belirtmiştir. Yaklaşık \%40'ının okullarından memnun olmadığını belirten Korkmaz, bu durumun öğrenciler tarafından öğretmenlerle ilişkilendirildiğini belirtmiştir. Arpacı ve Yıldırım'ın (2014) çalışması ise öğrencilerin okullarından memnun olduklarını göstermektedir. Çakır ve diğerleri 2004 yılında 59 öğrenci ile yaptıkları görüşme sonucunda imam hatip lisesinde okuduğu için pişman olan kimseye rastlamadıklarını belirtmişlerdir. Buna göre, öğrencilerin okullarından memnun oldukları söylenebilir. İmam hatip lisesi öğrencilerinin beklenti ve sorunlarını belirlemeye yönelik olarak yaptığı çalışmada Ünlü (1999), öğrencilerin okullarından memnun olduklarını (\%83.93) belirlemiştir. Aynı yöndeki bir başka çalışmada Türkmen Gül (1998) tarafindan elde edilen sonuç yine öğrencilerin okullarından memnun oldukları (\%80.8) yönündedir. İmam hatip lisesi öğrencilerinin okullarına karşı duydukları memnuniyeti tespit etmeye yönelik olarak yapılan diğer araştırmalarda da (Akdoğan, 1994; Karacoşkun, 1994; Kula, 1986) öğrencilerin okullarından büyük oranda memnun oldukları sonucuna ulaşılmıştır. Bununla birlikte, daha önce yapılmış olan çalışmalara bakıldığında, yıllar içerisinde imam hatip lisesi öğrencilerinin okullarına yönelik memnuniyet düzeylerinde dikkate değer düşüş meydana geldiği görülmektedir. Bu durum, Aşlamacı'nın (2017) bu yöndeki tespitini doğrulamaktadır.

$\mathrm{Bu}$ çalışmada ise, imam hatip lisesi öğrencilerinin okullarından memnun olma durumlarının dörtte bir oranına kadar düştüğü sonucuna ulaşılmıştır. $\mathrm{Bu}$ sonucun ortaya çıkmasında, okullarında temizliğin yeterli düzeyde olmaması, bazı arkadaşlarının can sıkıcı olumsuz davranışlar sergilemeleri, okulda sunulan akademik eğitimin kaliteli olmaması, idareci ve öğretmenlerini özverili görmemeleri, idareci ve öğretmenlerin davranışlarını kendilerine örnek teşkil edecek düzeyde görmemeleri gibi düşüncelerin öğrenciler arasında sıklıkla paylaşılmasının etkili olduğu görülmüştür. Bu durumun ortaya çıkmasında etkili olan bir diğer sebebin, öğrencilerin bu okulları tercihlerinde etkili olan faktörler olduğu göz önüne alınmalıdır. Her ne kadar okuldan duyulan memnuniyetsizliğin tamamını açıklayamasa da, öğrencilerin yaklaşık üçte birinin kendi istekleri d1şındaki bir etki ile bu okullara gelmiş olmaları, memnun olmama durumunun bir kısmının ön kabul ile gerçekleşmiş olabileceğini düşündürmektedir. Sonuç olarak görülmektedir ki, imam hatip lisesi öğrencilerinin memnuniyet düzeylerindeki düşüş devam etmektedir. 


\section{Öğrencilerin Okulla İlgili Öngördüğü Değişiklikler}

İmam hatip lisesi öğrencileri okullarına yönelik özellikle yönetim uygulamalarıyla ilgili değişiklikler öngörmektedirler. Buna göre, öğrenciler özellikle okul yönetimini değiştirilmesini ve kendilerine adaletli davranılması gerektiğini düşünmektedir. Bunun yanında, öğrenciler öğretmen kadrosunun da değiştirilmesini istemektedir. Yine öğrencilerin okullarında disiplinin sağlanacağı biçimde değişiklik istemeleri de dikkat çeken bir sonuç olarak ortaya çıkmıştır.

\section{Öğrencilerin İmam Hatip Liselerine İlişkin Çeşitli Konulardaki Görüsşleri}

İmam hatip lisesi öğrencileri, "imam hatip lisesini" dinî/manevî değerler ile ilişkili görmektedirler. Öğrencilerin, dinî bilgileri öğretmeyi bu okulların temel görevlerinin başında gördükleri belirlenmiştir. Bu bulgu, öğrencilerin bu okullardan beklentileri ile ilgili bulgular ile aynı yöndedir. Elde edilen bulgular, bu okulların çeşitli beceriler edindirmeye yönelik görevlerinin yanında, manevî değerleri kazandırmaya yönelik görevleri olduğunu da düşünen öğrencilerin varlığını göstermektedir. Ünlü (1999), “imam hatip lisesi nasıl olmalı?” sorusunu yönelttiği imam hatip lisesi öğrencilerinden yaygın olarak, ismine yakışır biçimde dürüst, çalışkan, ahlâklı öğrenciler yetiştiren, meslek eğitimi öncelikli olmak üzere her yönüyle kaliteli eğitimin verildiği bir yer olması gerektiğini vurgulayan cevaplar almıştır. Öğrencilerin, meslekî derslerin önceliğine vurgu yapmaları sebebiyle dinî ve özellikle vurguladıkları değerler itibariyle de manevî yönlerini öne çıkararak, imam hatip lisesini dinî/manevî bir çerçevede değerlendirdikleri söylenebilir. Arpacı ve Yıldırım (2014), imam hatip lisesi öğrencilerinin imam hatip lisesi kavramını şekillendiren ve hedefe ulaştıran olarak algıladıklarını, buna göre imam hatip lisesinin öğrenciler tarafından güven verici olarak algılandığını tespit etmiştir. Ayrıca, öğrencilerin bu okulların dinî bilgilerin öğrenildiği yer olduğuna dair kanaate sahip oldukları da belirlenmiştir. Arpacı ve Yıldırım (2014) bu durumu, öğrencilerin bu okullara yüklenen misyonun farkında oldukları biçiminde yorumlamıştır. Buna göre, çalışmadan elde edilen sonuç bu yönüyle, daha önce yapılmış çalışmalarla benzerlik göstermektedir.

İmam hatip lisesi öğrencileri "imam hatiplilik" kavramını dinî/millî/manevî değerlerle açıklamışlardır. Bunun yanında, bu kavramın her ne kadar öğrenciler tarafından önemli olarak ifade edildiği görülse de, bunun aksini belirten öğren- 
cilerin çokluğu da dikkate değerdir. Bu durum, bu okulları kendi isteği dışında tercih etmek zorunda kalan öğrencilerin varlığı ile açıklanabilir görülmektedir. Öğrencilere imam hatip lisesi öğrencisinin nasıl olmas1 gerektiğine dair soru yönelten Ünlü'nün (1999) aldığı yaygın cevaplar, bu kimliğin okulunu ve taş1dığı kimliği iyi şekilde temsil eden, şuurlu, dinî yönü gelişmiş, topluma örnek olacak davranışlar sergileyen bir yapıda olması gerektiğini göstermiştir. Ünlü (1999) ayrıca, öğrencilerin dinî kimlikleri ile vatanlarına ve milletlerine hizmet etmeyi istediklerini belirterek, bu okul ve öğrencilerle daha önce ilişkilendirilen dinî ve manevî değerlere millî değerleri de eklemiştir. İmam hatiplilik ile ilişkili olarak kabul edilebilecek bir çalışma Aşlamacı (2017) tarafından gerçekleştirilmiştir. Bu çalışmada öğrencilerin okulları ile ilgili aidiyet düzeyleri belirlenmeye çalış1lmıştır. Buna göre, öğrencilerin yaklaşık beşte üçü kendisini imam hatip lisesine ait hissetmektedir. Özensel ve Aydemir (2016: 124) ise araştırmalarında, imam hatipli olmanın aidiyet kaynağını, imam hatip öncesinde Kur'an kursu eğitimi ve dindar aileye mensup olma olarak belirtmişlerdir. Arpacı ve Yıldırım (2014) tarafından yapılan çalışmada ise, öğrencilerin ürettikleri metaforlar üzerinden, sorumluluk ve farkındalık duygusuna sahip oldukları öne sürülerek, bunun öğrencilerin imam hatipli olma ve imam hatip şuuru kavramlarına yönelik bilinç taşıdıkları anlamına geldiği belirtilmiştir. A. Doğan (2006) çalışmasında, imam hatip lisesi öğrencileri tarafından imam hatipli olmak kavramının iyi, ahlâklı, dürüst, iffetli ve hürmetkâr olmak ile vatanına, milletine faydalı insan olmak şeklinde ifade edildiğini belirtmiştir. Çakır ve diğerleri (2004) tarafından öğrenci, öğretmen ve mezunların imam hatiplilik olgusu üzerine görüşlerinin alındığı çalışmada, imam hatipliliğin milliyetçi-muhafazakâr kavramlarla ifade edildiği belirlenmiştir. Ayrıca, imam hatipli olmanın katılımcılar tarafından bazı değerleri temsil etmek olarak anlaşıldığının vurgulandığı çalışmada, bu sebeple toplum içerisindeki davranışlara azami şekilde dikkat edilmesinin gerektiği de katılımcılar tarafından belirtilmiştir.

İmam hatip lisesi öğrencileri, imam hatipli olduğunu toplum içinde ifade edebildiklerini, bu durum karşısında olumlu, olumsuz tepkiler aldıklarını belirtmişlerdir. Aşlamacı (2017) ve Karateke (2010) tarafından yapılan çalışmalarda da, öğrencilerin imam hatip lisesi öğrencisi olduklarını rahatlıkla ifade edebildikleri sonucu çıkmıştır. Araştırma bu yönüyle daha önce yapılmış çalışmalarla benzerlik göstermektedir.

İmam hatip lisesi öğrencileri, toplumun imam hatip lisesi öğrencilerinden beklentilerinin olumlu yönde olduğunu düşündüklerini belirtmişlerdir. Benzer 
sonuç A. Doğan (2006) tarafından yapılan çalışmada da görünmektedir. Sonuç olarak, imam hatip lisesi öğrencileri, toplumun kendilerinden dinî ve ahlâkî bir takım beklentiler içerisinde olduğunu düşünmektedirler. Bu sonuçların ortaya çıkmasında, ülkenin siyasî yöneliminin daha önceki dönemlere göre farklılaşması ve buna bağlı olarak özellikle medyanın bu okullara yönelik bakış açısının değişiklik göstermesi gibi etkenlerin etkili olduğu ileri sürülebilir. Bu noktada, özellikle medyanın 28 Şubat sürecinde izlediği yayın politikasının, toplumun bu okullara yönelik kanaatlerinin oluşmasında üstlendiği rol göz ardı edilmemelidir (A. E. Doğan, 2006; Tunahan, 2015).

İmam hatip lisesi öğrencilerinin kendilerine örnek/rehber olarak gördükleri şahsiyetler genel olarak dinî/millî/manevî değerleri temsil eden kişilerdir. Bunun yanında, imam hatip lisesi öğrencilerinin kendilerine örnek/rehber olarak benimsedikleri şahsiyetler arasında Hz. Muhammed'in (SAV) dile getirilme sıklı̆̆ının diğer şahsiyetlerle benzer düzeyde olması düşündürücüdür. Toplumda, bu okulların dinî eğitim sunma vasfı ile öne çıkmış olması ve öğrencilerin de bu okulları dinî eğitim için alternatifsiz olarak görmeleri ve tercih sebebi olarak beyan etmiş olmalarına rağmen, Hz. Muhammed'i (SAV) rehber/örnek addedenlerin azlığı çelişki olarak görülmektedir. Bu okulu inanç ve ideallerini yansıttığı için tercih ettiğini belirten öğrencilerin azlığı, yani toplum içerisinde bu okullara yüklenen misyonun farkında olarak, şuurlu biçimde tercihte bulunan öğrencilerin az olmasının da bu tablonun ortaya çıkmasında etkili olduğu düşünülmektedir. Bu durumun, imam hatiplilik kimliğinin yeniden üretilmesi sürecinde, Mermutlu'nun (2008) belirttiği gibi muhafazakâr kesimin dünyevileşmesinin bir sonucu olarak ortaya çıktığı öne sürülebilir.

İmam hatip lisesi öğrencilerinin öncelikli olarak çözülmesi gereken dünya sorunlarına yönelik düşünceleri, dinî/ahlâkî sorunlar ve insanî sorunlar etrafında toplanmıştır. Öğrenciler tarafından savaş, zulüm, ahlâk ve adalet kavramlarının öncelikli olarak dile getirilmiş olduğu görülmektedir. Özellikle dinî ve ahlâkî sorunların sıklıkla dile getirilmiş olması, alınan dinî eğitim vasıtasıyla hayatı anlamlandırma çabası içinde olduklarını düşündürmektedir. Buna göre diğer sorunların da, dinî ve ahlâkî çöküntünün bir sonucu olarak görüldüğü söylenebilir. Ayrıca, İslâm dünyasının içinde bulunduğu durumu olumsuzluklarla ilişkilendiren öğrencilerin çoğunlukta olması, bu yöndeki tartışmalara kaynaklık eden düşüncelerin öğrenciler tarafından da paylaşıldığını göstermektedir.

Tüm bu sonuçlardan elde edilen bilgiler doğrultusunda, öğrencilerin imam hatip liselerine ilişkin çeşitli konulardaki sorulara genel olarak dinî/millî/ma- 
nevî değerler çerçevesinde cevaplar verdiği görülmektedir. Bu durum önceki çalışmalarda (Akşit ve Coşkun, 2005: 394; Aşlamacı, 2017; Çakır ve diğerleri, 2004; A. Doğan, 2006; Gökaçt1, 2005; Macit, 2014; Mermutlu, 2008; Özensel ve Aydemir, 2016; Subaş1, 2004; Ünlü, 1999) ortaya çıkan, imam hatipliliğin milliyetçi/muhafazakâr değerler çerçevesinde şekillendiği yönündeki söylemleri kuvvetlendirmektedir.

\section{İmam Hatip Lisesi Mezunlarının Bu Okulları Tercih Etme Sebepleri}

İmam hatip lisesi mezunlarının bu okulu tercih etme sebeplerinin aile isteği ve kendi tercihleri olduğu ortaya çıkmıştır. Bu sebeplerle bu okullara kaydolduğunu belirten mezun oranının, günümüz öğrencilerinden yine aynı sebeplerle bu okula kaydolanlara göre daha yüksek olduğu görülmektedir. Bunun yanında, bir ideal veya inancı önceleyerek bu okulu tercih ettiğini belirten mezun oranı da, günümüz öğrencilerinin aynı yöndeki oranından yüksektir. Bir başka deyişle, çoğunluğunu 2000 yılı öncesinde imam hatip lisesine kaydolmuş kişilerin oluşturduğu mezunlardan elde edilen verilere bakıldığında, bu okulları tercih etme sebepleri yönünden, günümüz imam hatip lisesi öğrencilerine göre, "ideal/şuur/ülkü" sahibi olma kıstasını daha fazla dikkate aldıkları görülmektedir. $\mathrm{Bu}$ durum, "imam hatiplilik" olarak nitelendirilebilecek bilincin, imam hatip kurumları ve bu okul öğrencileri için daha sıkıntılı geçtiği düşünülen yıllarda, günümüze oranla daha etkili olduğunu düşündürmektedir.

İmam hatip lisesi mezunların bu okullarla ilgili deneyimleri sonucunda, bu okullara yönelik olumlu bir tutum içerisinde bulundukları görülmektedir. Tekrardan tercih etme hakkı olsa bu okulları tercih etmeyeceğini ifade eden günümüz imam hatip lisesi öğrencilerinin aksine, mezunların neredeyse tamamı tercihlerini yine bu okullardan yana kullanacaklarını beyan etmişlerdir. Bu durum, mezunların bu okulla ilgili bir mensubiyet hissini halen taşıdıkları şeklinde anlaşılmaktadır. Mezunların imam hatip liselerini tekrar tercih edip etmeyeceğine dair kanaatlerini alan Cebeci (1989), büyük çoğunlukla bu okulların tekrar tercih edileceği sonucuna ulaşmıştır. Yaklaşık 30 yıl arayla benzer soruyu soran iki araştırmanın benzer bu bulgusu, imam hatip liselerinin mezunlarında istikrarlı biçimde aidiyet (ya da memnuniyet) oluşturabildiği biçiminde yorumlanabilir. Halen öğrenci olanların ya da yeni mezunların okullarına gelecekte nasıl yaklaşacakları ise gelecek araştırmalar için işlevsel bir araştırma sorusu olabilir. Bunun yanında mezunlara göre, toplum günümüzde imam hatip liselerine kendi dönemlerine göre daha olumlu bakmaktadır. Yani, kendi öğrencilik dönemleri- 
ne göre, günümüz toplumunda imam hatip liselerine yönelik genele yayılmış bir olumsuzluk olmadığı kanaatindedirler. İmam hatip lisesi mezunları, günümüz öğrencilerinin aksine, kendi dönemlerinde imam hatip lisesinin sunduğu eğitim-öğretimden yüksek düzeyde memnundurlar. Cebeci (1989) de, imam hatip lisesi mezunlarının bu okullarda okumaktan yüksek düzeyde memnun olduklarını ortaya çıkarmıştır. Her iki çalışma arasında benzerlik görülmektedir.

\section{İmam Hatip Lisesi Mezunlarının Bu Okulların Dünü, Bugünü ve Yarını Hakkındaki Düşünceleri}

Ayrıca, mezunlar kendi öğrencilik dönemlerindeki öğretmenlerini de gayretli olarak nitelemişlerdir. Bunun yanında, kendi öğrencilik dönemlerinde imam hatip lisesinde okuduklarını rahatlıkla ifade edebildiklerini de belirtmişlerdir. Günümüzde imam hatip liselerinin öğrenci sayısının artmasına rağmen kalitesinin düştüğü fikrini savunan mezunlar, günümüz okullarında fizikî şartların iyi, ancak öğrenci ve eğitim kalitesinin düşük olduğunu ifade etmişlerdir. Mezunlar, günümüz imam hatip liselerini, dinî değerleri önceleyen bir eğitim kurumu olarak tanımlayamamaktadırlar. Toplumda dinî kavramlarla özdeşleşmiş bir imaja sahip olmasına rağmen, mezunların günümüz okullarını bu şekilde tanımlamakta kararsız kalmasının nedeni, kendi öğrencilik dönemlerinde içinde bulundukları şartları, idealler ve değerler yönünden daha olumlu görüyor olmalarıyla açıklanabilir. Günümüzde siyasilerin söylem ve davranışlarının imam hatip liselerine olan ilgiliyi artırdığını belirten mezunlar, bu okulların siyasetle ilişkilerinin geçmiş dönemlere göre daha kuvvetli olduğu konusunda belirgin bir kanaate sahip değildirler.

İmam hatip lisesi mezunlarına göre gelecekte, din eğitimi konusunda imam hatip liseleri alternatifsiz olacaklardır. Aynı zamanda, onlara göre toplumun imam hatip liselerine daima ihtiyacı olacaktır. Gelecekte bu okulların toplumsal birleştiricilik rolünü devam ettireceğini ve bu okullarda daha kaliteli eğitim verileceğini düşünen mezunlar, imam hatip liselerinin şuurlu nesil yetiştirmesi konusunda ise geleceğe dair kararsızlık içindedirler. Gelecekte imam hatip liselerinin önüne yeni engeller konulup konulmayacağına yönelik önerme de kararsızlıkla karşılanmıştır. Bu sonuç ise, katılımcıların geçmiş dönemin tecrübelerinin oluşturduğu tedirginliklerini taşıdıklarını göstermektedir. Çakır ve diğerleri (2004) tarafından yapılan çalışmada, imam hatip lisesi mezunlarının bu okulların geleceği hakkındaki görüşleri alınmıştır. İmam hatip lisesi mezunları ile görüşme şeklinde yapılan çalışmada, bu konudaki mezun görüşlerinden 
bazılarına yer verilmiştir. Çalışmada, mezunların geneli bu okulların geleceği hakkında umutlu görünmektedirler. Bunun yanında, imam hatip lisesi mezunlarından bazıları, bu okulların miadının dolduğunu ve geleceklerinin olmadığına dair görüş belirtmişlerdir. Belirtilen olumsuz görüşlerin özellikle, o dönemde henüz çözüme kavuşturulmamış olan ve imam hatip lisesi öğrencilerinin üniversiteye girişlerinde olumsuz etkiye sebep olan katsayı uygulamasının devam ediyor olmasından ötürü ortaya çıktığı değerlendirilebilir.

\section{İmam Hatip Lisesi Mezunlarının Bu Okullarda Öngördüğü Değişiklikler}

İmam hatip lisesi mezunlarının bu okullarda yapılmasını gerekli gördükleri öncelikli değişiklikler eğitim-öğretim ile ilgilidir. Bu sonuç, kendi dönemlerindeki eğitim-öğretimin kalitesini, günümüz öğrencilerinin aynı yöndeki değerlendirmelerine göre, daha yüksek düzeyde görmeleri ile de ilişkili görülmektedir. Çakır ve diğerleri (2004) tarafından yapılan çalışmada ise, imam hatip liselerinin niteliğindeki fark edilir düşüşü önemli ve çözüm üretilmesi gerekli bir sorun olarak belirten mezunlar, bu durumun sebebini katsayı uygulaması sonucunda bu okullara öğrenci teminindeki zorluklar olarak belirtmişlerdir. 2004 yılında gerçekleştirilmiş olan çalışmada, uygulanmaya devam eden katsayı uygulamasının bir sonucu olarak üniversite öğrenimini önceleyen öğrencilerin imam hatip liselerini tercih etmemelerinin bir sonucu olarak bu okulların kayıtlı öğrenci sayılarında düşüşler yaşanmıştır. Bunun bir sonucu olarak, özellikle öğrencilerin kendi isteklerini tam olarak yansıtmayan biçimde bu okullara kaydedilmesi veya lise öğrenimini düşünmeyenlerin sırf okul kapanmasın diye kaydedilmesi gibi sebeplerden ötürü bu okulların niteliğinde gerilemeler yaşanmıştır. Buna göre, Çakır ve diğerleri (2004) tarafından çalışmanın yapıldığı dönemde değişik etkiler sonucu ortaya çıkan nitelik tartışmalarının farklı sebeplerle devam ettiği görülmektedir. O dönem için niceliksel küçülmeye bağlı olarak yaşanan nitelik tartışmalarının yanında, günümüzde niceliksel büyümeye bağlı olarak yaşanan nitelik tartışmalarının varlığından söz etmek mümkündür. Bu hususta mezunlar, imam hatip liselerinin kontrolsüz biçimde her yere yaygınlaştırılmasının niteliği düşürdüğünü ve bu okulların değerinin azalmasına sebep olduğunu belirtmişlerdir. Bu yönüyle çalışma, Çakır ve diğerleri (2004) tarafından yapılan çalışmayla benzer yönde sonuçlara ulaşmıştır. 


\section{Sonuç}

Sonuç olarak, imam hatip lisesi öğrencilerinin bu okulları daha çok kendileri dışındaki etkenlerle tercih ettiği görülmektedir. Bununla birlikte öğrenciler, lise öğrenimiyle birlikte dini bilgileri de edinmek amacıyla bu okullara gelmektedir. Öğrencilerin genel anlamda okullarından bir memnuniyetsizlikleri olduğu dikkat çekmektedir. Öğrenciler bu noktada okul yönetimlerinden beklenti içindedirler. Mezunların görüşleri ile birlikte ele alındığında geçmişten günümüze imam hatip liselerinin daha iyiye gitmediği değerlendirmesi yapılabilir. Anlaşılan odur ki, toplumun önemli bir kesiminin ve bu okulların öğrencilerinin beklentilerini karşılamak adına imam hatip liselerinde makro ve mikro düzeyde nitelik odaklı politikalar izlenmesi, okul ve öğrenci sayısı yerine bu okulların süreçlerine ve çıtılarına odaklanılması daha işlevsel bir yaklaşım olacaktır.

\section{Kaynakça}

Akınc1, A. (2013). Türk siyasal hayatında 1980 sonrası darbeler ve e-muhtıra. Trakya Üniversitesi Sosyal Bilimler Dergisi, 15(2), 39-58.

Akdoğan, A. (1994). Imam-hatip liselerinde okutulan hadis dersi programının değerlendirilmesi (Yayımlanmamış yüksek lisans tezi). Ondokuz Mayıs Üniversitesi Sosyal Bilimler Enstitüsü, Samsun.

Akşit, B. ve Coşkun, M. K. (2005). Türkiye'nin modernleşmesi bağlamında imamhatip okulları. T. Bora, M. Gültekingil (Ed.), Modern Türkiye'de siyasî düşünce İçinde (s. 394-410). İstanbul: İletişim Yayınları.

Arpac1, M. ve Yıldırım, C. (2014). İmam hatip lisesi öğrencilerinin, "imam hatip lisesi" ve "imam hatip liseli olmak" kavramlarına yönelik görüşlerinin metafor analizi yoluyla incelenmesi (Diyarbakır örneği). Toplum Bilimleri Dergisi, 8(15), 135-152.

Aşlamacı, İ. (2017). Öğrenci ve ögretmenlerine göre imam-hatip liseleri: Profiller, algılar, memnuniyet, aidiyet. İstanbul: Değerler Eğitimi Merkezi.

Ateş, P. (2016). İmam hatip lisesinde okuyan öğrencilerin imam hatip lisesini tercih nedenleri ve beklentileri (Gaziantep örneği) (Yayımlanmamış yüksek lisans tezi). Gaziantep Üniversitesi Sosyal Bilimler Enstitüsü, Gaziantep.

Baki, A. ve Gökçek, T. (2012). Karma yöntem araştırmalarına genel bir bakış. Elektronik Sosyal Bilimler Dergisi, 11(42), 1-21.

Büyüköztürk, Ş., Çakmak, E. K., Akgün, Ö. E., Karadeniz, Ş. ve Demirel, F. (2010). Bilimsel araştırma yöntemleri. Ankara: Pegem Akademi. 
Cebeci, S. (1989). Orta ögrretimde meslekî din eğitiminden mezun olanların yönelişleri ve sebepleri (Yayımlanmamış yüksek lisans tezi). Ankara Üniversitesi Sosyal Bilimler Enstitüsü, Ankara.

Cebeci, S. (1995). İmam-hatip liselerinin öğrenci yapısı ve bunun sosyal gelişme açısından değerlendirilmesi. Harran Üniversitesi Illahiyat Fakültesi Dergisi, 1, 111-120.

Çakır, R., Bozan, İ. ve Talu, B. (2004). İmam hatip liseleri: Efsaneler ve gerçekler. İstanbul: TESEV Yayınları.

Çarkoğlu, A. ve Kalaycığlu, E. (2009). Türkiye'de dindarllk: Uluslararası bir karşılaştırma. İstanbul: Sabancı Üniversitesi.

Doğan, A. (2006). 1997 yllından sonraki dönemde imam-hatip liselerindeki gelişmeler (Adana örneği) (Yayımlanmamış yüksek lisans tezi). Çukurova Üniversitesi Sosyal Bilimler Enstitüsü, Adana.

Doğan, A. E. (2006). Siyasal yansımalarıyla İslamcı sermayenin gelişme dinamikleri ve 28 Şubat süreci. Mülkiye Dergisi, 30(252), 47-68.

Doğan, R. (2017). Yaygın din eğitiminin neliği. R. Doğan ve R. Ege (Ed.), Din eğitimi İçinde (s. 275-294). Ankara: Grafiker Yayınları.

Dolmacı, E. (2018). İmam hatiplere bakış 2017. Erişim adresi: http://www.onder. org.tr/Content/pdf/Papers//671b1707-5152-4ba1-93f2-17871853a29f.pdf

Ergin, O. N. (1977). Türk maarif tarihi. İstanbul: Eser Matbaası.

Ertem, B. (2018, Nisan). 28 Şubat 1997 "post-modern" askeri müdahalesi ve medya. 1. Uluslararası Eğitim ve Sosyal Bilimlerde Yeni Ufuklar Kongresi'nde sunuldu, İstanbul.

Gökaçt, M. A. (2005). Türkiye'de din eğitimi ve imam hatipler. İstanbul: İletişim Yayınları.

Görmez, M. ve Coşkun, İ. (2015). 1. yllında temel eğitimden ortaöğretime geçiş reformunun değerlendirilmesi. Ankara: Siyaset, Ekonomi ve Toplum Araştırmaları Vakfi.

Karacoşkun, M. D. (1994). İmam-hatip lisesi öğrencilerinin dini tutum ve davranışları (Yayımlanmamış yüksek lisans tezi). Ondokuz Mayıs Üniversitesi Sosyal Bilimler Enstitüsü, Samsun.

Karasar, N. (2012). Bilimsel araştırma yöntemi. Ankara: Nobel.

Karateke, T. (2010). Imam-hatip lisesi ögrencilerinin sorun ve beklentileri (Batman örneği) (Yayımlanmamış yüksek lisans tezi). Fırat Üniversitesi Sosyal Bilimler Enstitüsü, Elazı̆̆.

Korkmaz, M. (2013). İmam hatip lisesi öğrencilerinin bu okulu tercih süreçleri. Erciyes Üniversitesi Ilahiyat Fakültesi Dergisi, 1(16), 7-40. 
Kula, M. N. (1986). Ergenlerde kimlik bunalımı ve din eğitiminin etkisi (Yayımlanmamış yüksek lisans tezi). Uludağ Üniversitesi Sosyal Bilimler Enstitüsü, Bursa.

Macit, M. (2014). Sosyal medyada “imam hatipli” temsilleri: Kolektif bir kimlik söylemindeki sosyal-bilişsel izdüşümler. Atatürk Üniversitesi Türkiyat Araştırmaları Enstitüsü Dergisi, 51, 379-394.

MEB (2019). 2023 Eğitim Vizyonu. Erişim adresi: http://2023vizyonu.meb.gov.tr/

Mermutlu, B. (2008). İmam-hatip liseleri'nin seküler açmazı. Akademik Araştırmalar Dergisi, 38, 87-98.

Öcal, M. (1994). İmam-hatip liseleri ve ilköğretim okulları. İstanbul: Ensar Neşriyat.

Öcal, M. (2007). Türk hukuk mevzuatında din eğitimi ve öğretiminin yeri ve uygulama biçimi. İ. Çelebi (Ed.), Avrupa birliği sürecinde dinî kurumlar ve din eğitimi İçinde (s. 511-559). İstanbul: Ensar Neşriyat.

Öcal, M. (2015). Osmanlı'dan günümüze Türkiye'de din eğitimi. İstanbul: Dergâh Yayınlar1.

Özcan, M. (2010). Anadolu meslek lisesi öğrencilerinin okudukları okulu seçme nedenleri ve gelecek beklentileri (Yayımlanmamış yüksek lisans tezi). Selçuk Üniversitesi Sosyal Bilimler Enstitüsü, Konya.

Özdemir, Ş. ve Karateke, T. (2018). Öğrencilerin imam hatip liselerini tercih etme nedenleri (Elazığ örneği). Ondokuz Mayıs Üniversitesi Ilahiyat Fakültesi Dergisi, 45, 5-33.

Özensel, E. ve Aydemir, M. A. (2016). Türkiye'de imam hatipli olmak: Temel sorunlar, beklentiler ve değer yapıları. Konya: Çizgi Kitabevi.

Subaşı, N. (2004). İmam hatip(li)ler üzerine: Teolojik birikimin modern kaynakları. Değerler Eğitimi Dergisi, 2(6), 115-132.

TİMAV (2014). Türkiye imam hatip lisesi ögrenci profili araştırmasl (Temel sorunlar, beklentiler ve değer yapılart). Erişim adresi: http://timav.org.tr/ wp-content/uploads/2016/03/T\%C3\%BCrkiye-\%C4\%B0mam-Hatip-Lisesi- $\%$ C3\%96\%C4\%9Frenci-Profili-Ara $\%$ C5\%9Ft $\%$ C4\%B1rmas\%C4\%B1.pdf

Topçu, N. (2016). Türkiye’nin maarif davası. İstanbul: Dergâh Yayınları.

Tunahan, Ö. (2015). 28 Şubat süreci: 'Post-modern darbe'nin sosyo-politik dinamikleri ve toplum desteği. Bilgi, 30, 23-41.

Türkmen Gül, E. (1998). İmam-hatip lisesi ögrencilerinin beklenti ve sorunlarl (Yayımlanmamış yüksek lisans tezi). Uludağ Üniversitesi Sosyal Bilimler Enstitüsü, Bursa.

Ünal, İ. Ö. (2008). Sakarya ilinde imam hatip algısı (Yayımlanmamış yüksek lisans tezi). Gazi Üniversitesi Sosyal Bilimler Enstitüsü, Ankara. 
Ünlü, Y. (1999). İmam-hatip lisesi ögrrencilerinin beklenti ve sorunları (Bursa merkez ve ilçeleri İHL örneği) (Yayımlanmamış yüksek lisans tezi). Uludağ Üniversitesi Sosyal Bilimler Enstitüsü, Bursa.

Yayla, A. (2005). Eğitim kavramının etik açıdan analizi. YYÜ Ĕ̆itim Fakültesi Dergisi, 2(1), 1-12.

Yüksel, E. (2012). 28 Şubat sürecinde milli güvenlik kurulu ve medya gündemi ilişkisi. İstanbul Üniversitesi Illetişim Fakültesi Dergisi, 19, 69-82. 
Extended Abstract

\title{
Evaluation of Imam Hatip High Schools from the Students and the Graduates' Perspective
}

\author{
Ömer Alper KARASUBAŞI, Teacher. \\ Republic of Turkey Ministry of National Education, Turkey. \\ omaralper@gmail.com \\ http://orcid.org/0000-0001-6399-2180
}

Uğur AKIN, Corresponding Author, Associate Professor.

Tokat Gaziosmanpaşa University, Faculty of Education, Turkey.

akinuur@gmail.com

http://orcid.org/0000-0002-4911-3781

Nail YILDIRIM, Professor.

Kahramanmaraş Sütçü İmam University, Faculty of Education, Turkey.

nailyildirim@ksu.edu.tr

http://orcid.org/0000-0002-4681-9498

Article Type: Research Article

https://doi.org/10.34234/ded.602051

Received Date: 05.08 .2019

Accepted Date: 19.12.2019

Published Date: 25.06.2020

\section{Introduction}

Imam Hatip high schools, which have been the subject of positive and negative debates since they first took place in the Turkish education system, followed a fluctuating course as a result of the political and social conditions of the period they existed in. As a part of the political and social debates for many years, all citizens, whether or not they send their children to Imam Hatip high schools, can be said to be somehow familiar with the discussions around these schools and have idea about them. Given the historical ups and downs that Imam Hatip 
high schools went through, nowadays they have reached the highest number of schools and students of the Republican period in terms of quantity, it would not be wrong to call the recent period as the "rise" of these schools. While many relevant and irrelevant parties are expressing opinions about Imam Hatip High Schools, which have got rid of its hurdles and sailed itself into the "prevailing winds", determining the views of its students and graduates on various issues related to these schools is important in terms of making a realistic description of the state of Imam Hatip high schools.

Research into this subject has shown that these schools are preferred for some reasons such as the desire to learn religious issues better (Cebeci, 1995) or student's own will (Aşlamac1, 2017; Ateş, 2016; Çakır, Bozan, and Talu, 2004; A. Doğan, 2006; Karateke, 2010; Korkmaz, 2013; Özensel and Aydemir, 2016). On the other hand, studies show that with the influence of different placement systems applied in the transition to secondary education, some students prefer these schools involuntarily due to the "orientation of the current system after middle school", while others have to prefer these schools since "their score matches only these schools" (Aşlamac1, 2017; Görmez and Coşkun, 2015). There are also studies suggesting that student expectations from Imam Hatip high schools is to get high-quality education (A. Doğan, 2006) and learning religious subjects better (Ateş, 2016; Karateke, 2010). In addition to these, some studies have been observed to explain the expectations of students from vocational and cultural courses through the attitudes of students towards teachers. As for the satisfaction of the students, some studies show that students are satisfied with these schools to a great extent (Akdoğan, 1994; Arpacı and Yıldırım, 2014; Çakır et al., 2004), while others indicate that the satisfaction levels of students have decreased compared to previous years (Aşlamac1, 2017; Korkmaz, 2013). Although there has been as much as a two-and-a-half-fold increase in the number of students and a four-fold increase in the number of schools in today's Imam Hatip high schools, no studies have been found in the literature of recent years investigating students' preferences, expectations, and satisfaction, which is considered as a gap in the field.

This study aimed to determine the opinions of Imam Hatip high school students and its graduates on various issues related to Imam Hatip high schools and what it means to be an Imam Hatip high school student. For this purpose, the study sought answers to the following questions: 
1. What are the reasons why Imam Hatip high school students prefer these schools?

2. What do Imam Hatip high school students expect from their schools?

3. What are the satisfaction levels of Imam Hatip high school students in terms of meeting their expectations?

4. What changes do Imam Hatip high school students want to make in their schools?

5. What are the opinions of Imam Hatip high school students on various issues related to their schools?

6. What are the reasons why graduates of Imam Hatip high schools preferred these schools and what are their current tendencies to choose these schools?

7. What are the opinions of Imam Hatip high school graduates about the past, present and future status of Imam Hatip high schools?

8. What changes do Imam Hatip high school graduates want to make in these schools?

\section{Method}

This study used a mixed-method based on the application of both quantitative and qualitative research methods. In the quantitative and qualitative parts of the study, three different working groups were determined to collect data from students and graduates. The first study group consisted of 254 students selected among a population of 802 students enrolled in Tokat Anatolian Imam Hatip High School in the 2017-2018 academic year. The second study group consisted of 28 students selected among the population of 802 students described above by maximum variation sampling. On the other hand, the third study group was made up of 158 Imam Hatip high school graduates across Turkey, who was reached by employing the simple random sampling technique. A data collection tool was created for each study group to obtain quantitative and qualitative data. The arithmetic averages, frequencies and percentages of the opinions obtained from the sections created in the five Likert type were determined, as one of the data collection tools applied to students and gratuates. Also, content analysis was conducted for open-ended questions in the data collection tool.

\section{Results and Discussion}

The majority of Imam Hatip high school students who participated in the study were found to prefer these schools as a result of their families' orientation. Pre- 
vious studies (Aşlamacı, 2017; Ateş, 2016; A. Doğan, 2006; Karateke, 2010; Korkmaz, 2013; Özcan, 2010; Özensel and Aydemir, 2016; Türkmen Gül, 1998; Ünal 2008; Ünlü, 1999) reported that student and family desire was often decisive in students' preference for Imam Hatip high school. In this study, on the other hand, the top five reasons of the students to choose Imam Hatip High School were determined to be the family impact, failing to win the desired school, provision of religious education, the manifestation of student's own wishes, belief, and ideals. Accordingly, the findings of the study differed from the findings of the aforementioned studies and showed that the impact of family orientation on the students' preferences increased and that a new factor such as failing to win the desired school emerged.

The Imam Hatip high school students who participated in the study expect to learn religious knowledge in these schools. In the study conducted by Karateke (2010), students stated that besides expecting to learn religious knowledge, the expect to find opportunities to apply the religious knowledge they gained. In a study on determining the expectations of Imam Hatip high school students, Ateş (2016) concluded that students expected to learn religious knowledge. In addition to these studies, which support the findings of the present study, A. Doğan (2006) reported that students' expectations from these schools generally centered on receiving good quality education. Accordingly, students' expectations of good quality education cover both religious/vocational and general education.

Another important result obtained from the study was that students who aim to become a religious official were the minority among Imam Hatip high school students. In studies conducted before 2000 (e.g. Türkmen Gül, 1998; Ünlü, 1999), the number of students who wanted to become a religious official after graduating from these schools was observed to make up at least half of the total Imam Hatip high school students. The present study differs from previous studies in this respect.

Imam Hatip high school students expect vocational teachers to increase the quality of teaching and learning. In particular, the idea that vocational courses are not taught effectively enough is common opinion among students. The same applies to expectations from the teachers of culture courses. In his study, Asslamacı (2017) found that the process of teaching vocational courses did not adequately meet the expectations of Imam Hatip high school students. Karateke (2010), on the other hand, stated that Imam Hatip high school students expected teachers of vocational and cultural courses to be more interested engaging 
students. In this respect, the current study laid out results similar to those of previous studies.

Imam Hatip high school students do not generally look satisfied with the school conditions. The majority of the students stated that if they were to decide today they would not choose going to Imam Hatip High School. This result can also be interpreted as the loss of these students' feelings of belonging to these schools. The fact that students did not agree on any of the positive propositions that aimed to determine their level of satisfaction but that they generally agreed on negative ones strengthens this opinion. In the study conducted by Aşlamacı (2017), half of Imam Hatip high school students were found to be satisfied with their schools. Korkmaz (2013) stated that students often attached their satisfaction to receiving religious education. Reporting that around $40 \%$ of the students were not satisfied with their schools, Korkmaz indicated that students attached this dissatisfaction with teachers.

The changes that Imam Hatip high school students want to make in their schools, cover particularly the managerial practices. Accordingly, the students think that school management should be changed and that they should be treated fairly. The students also want a change in teaching staff. Furthermore, students want some changes that maintain discipline in their school, which is another striking result.

The students of the Imam Hatip high school consider these schools to be associated with religious/spiritual values. Students were found to consider the main task of these schools as teaching religious knowledge. Ünlü (1999) asked Imam Hatip high school students how these schools should be. The responses emphasized that Imam Hatip high schools should be a place where good quality education is given in all aspects, including primarily vocational education, which raises honest, hard-working, moral students worthy of its name.

The students of Imam Hatip high school explained the concept of belonging to Imam Hatip schools with religious/national/spiritual values. Ünlü (1999) asked the students how a student of Imam Hatip high school should be, and the common answers indicated that a student carrying this identity should represent their school well, having well-developed consciousness, and exhibit model behaviors for the society.

Another study that could be considered related to the feeling of belonging to Imam Hatip high school was carried out by Aşlamac1 (2017). According to the 
results obtained in this study, approximately three-fifths of students felt that they have sense of belonging to Imam Hatip high schools.

Imam Hatip high school students stated that they think the society holds positive expectations for Imam Hatip high schools. A similar result was obtained from a study carried out by A. Doğan (2006). In conclusion, Imam Hatip high school students were found to think that society had some religious and moral expectations from them.

The personalities that Imam Hatip high school students see as role models/ guides are generally those who represent religious/national/spiritual values. Besides, that the frequency with which the Prophet Muhammad (SAV) is mentioned among the personalities adopted by Imam Hatip high school students as a role model/guide is similar to that of other personalities is engrossing. Although these schools have become prominent in the society with the characteristic of offering religious education and that the students see these schools as irreplaceable for religious education and declare them as a reason of preference, the scarcity of those who consider the Prophet Muhammad (SAV) as a role model/ guide reveals a contradiction.

The reasons why Imam Hatip high school graduates preferred this school were found to be the family desire and their own preferences. The rate of graduates stating that they were enrolled in these schools for these reasons were found to be higher than the rate of current students enrolled in this school for the same reasons. Also, the rate of graduates stating that they preferred this school by prioritizing an ideal or belief was found to be higher than the rate of current students preferring this school for the same reason.

As a result of the experiences of Imam Hatip high school graduates in these schools, they were observed to have a positive attitude towards these schools. Unlike today's Imam Hatip high school students who state that they would not prefer these schools if they had another chance to choose a school again, almost all of the graduates declared that they would prefer these schools again. Cebeci (1989), who investigated the opinions of graduates whether they would prefer Imam Hatip high schools again, concluded that these schools would be preferred again. This similar finding of two studies that asked the same question with 30-year interval can be interpreted as the fact that the feeling of belonging (or satisfaction) was established in Imam Hatip high school graduates.

Besides, the graduates described their own teachers' performance as diligent. They also stated that they could easily state they were an Imam Hatip high 
school student when they were students. The graduates who claimed that the quality of Imam Hatip high schools fell despite the increased number of students today stated that the physical conditions were good in today's schools, but the quality of students and education was low. The graduates were determined to be unable to define today's Imam Hatip high schools as an educational institution that prioritizes religious values.

According to the graduates of Imam Hatip high schools, Imam Hatip high schools will be irreplaceable in the future in terms of religious education. At the same time, according to them, society will always need Imam Hatip high schools. The graduates who think that these schools will maintain their social unification role in the future and that the quality of education will be increase in these schools are indecisive about the future of Imam Hatip high schools. 